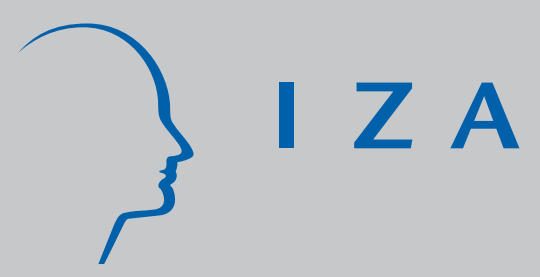

IZA DP No. 2258

Pulls, Pushes and Entitlement Failures in Labor Markets: Does the State of Development Matter?

Sumon Kumar Bhaumik

Ralitza Dimova

J effrey B. Nugent

August 2006 


\title{
Pulls, Pushes and Entitlement Failures in Labor Markets: \\ Does the State of Development Matter?
}

\author{
Sumon Kumar Bhaumik \\ Brunel University and IZA Bonn \\ Ralitza Dimova \\ Brunel University \\ Jeffrey B. Nugent \\ University of Southern California
}

Discussion Paper No. 2258

August 2006

\author{
IZA \\ P.O. Box 7240 \\ 53072 Bonn \\ Germany \\ Phone: +49-228-3894-0 \\ Fax: +49-228-3894-180 \\ Email: iza@iza.org
}

Any opinions expressed here are those of the author(s) and not those of the institute. Research disseminated by IZA may include views on policy, but the institute itself takes no institutional policy positions.

The Institute for the Study of Labor (IZA) in Bonn is a local and virtual international research center and a place of communication between science, politics and business. IZA is an independent nonprofit company supported by Deutsche Post World Net. The center is associated with the University of Bonn and offers a stimulating research environment through its research networks, research support, and visitors and doctoral programs. IZA engages in (i) original and internationally competitive research in all fields of labor economics, (ii) development of policy concepts, and (iii) dissemination of research results and concepts to the interested public.

IZA Discussion Papers often represent preliminary work and are circulated to encourage discussion. Citation of such a paper should account for its provisional character. A revised version may be available directly from the author. 
IZA Discussion Paper No. 2258

August 2006

\section{ABSTRACT \\ Pulls, Pushes and Entitlement Failures in Labor Markets: Does the State of Development Matter?*}

This study adapts a relatively novel model of off-farm labor supply to the changing conditions of Bulgaria during the 1990s. The model's parameters are estimated separately for each of the three different waves of the Bulgarian Integrated Household Survey, each reflecting remarkably different environmental conditions. Both the parameter values and the changes therein from one survey year to another are explained and used to characterize the way different types of households allocate their labor between farm and off-farm activities. The results demonstrate that Bulgarian households display many of the same labor supply patterns, including entitlement failures, as have previously been observed only in very poor developing countries. As such, they have potentially important policy making implications.

JEL Classification: J2, P23, P36, O13, Q12

Keywords: off-farm labor supply, diversification, entitlement failures, transition economies, Bulgaria, institutional change

Corresponding author:

Ralitza Dimova

Brunel University

Brunel Business School

Social Sciences Building

Uxbridge UB8 3PH

United Kingdom

E-mail: Ralitza.Dimova@brunel.ac.uk

\footnotetext{
* The authors would like to thank Joep Konings, Jo Swinnen, Gauthier Lanot and seminar participants at Queen's University Belfast, St. Anthony's College at Oxford University, and the 2004 annual meeting of the Royal Economic Society for their comments. They remain responsible for all remaining errors.
} 


\section{Introduction}

Development economists have traditionally viewed the migration of labor from the farm to the non-farm (or off-farm) sector as being desirable, indeed, manifesting a structural change in the economy that is consistent with industrialisation and growth (Lewis, 1954). More recently, focus has shifted to another phenomenon, namely, the supply of members of farm households to the off-farm sector, without the abandonment of farm related activities. Indeed, the supply of off-farm labor by farm households is fairly widespread, and can be found in both rich countries like the United States and Canada (e.g., Huffman, 1980; Weersink et al., 1998) and much poorer countries like those of sub-Sahara Africa, Asia and Latin America ( e.g., Escobal, 2001; Woldehanna and Oskam, 2001; Oldenhanna and Oskan, 2001; de Janvry and Sadoulet, 2001; Deringer and Olinto, 2001; Lamb, 2003; Joliffe, 2004).

The empirical literature on off-farm labor supply by farm households has proceeded in quite different ways, depending on the type of country. Studies of mature market economies are almost invariably based on the neoclassical assumption that utility-maximising individuals from farm households would supply labor to the off-farm sector if their marginal productivity in off-farm activities were to exceed their marginal productivity in farm activities (Huffman, 1980; Sumner, 1982). This line of argument has been extended to argue that if an individual from a farm household were more productive in the off-farm sector, she would work off-farm and, if needed, hire farm laborers to take her place on the farm (Benjamin, 1992). Further, it is argued that, instead of unilaterally maximizing utility through one's own labor allocation between farm and non-farm activities, one may arrive at a superior solution if the married couple or the household as a whole would jointly determine its labor allocations (Huffman and Lange, 1989).

On the other hand, the empirical literature on off-farm labor supply by farm households in developing countries views off-farm labor supply as a way to smooth consumption across time (Lanjouw and Lanjouw, 1995). Usually, such studies see off-farm labor supply as an ex post reaction to low farm income, leading to the testable hypothesis that agricultural income and the likelihood (or amount) of off-farm labor supply by farm households in these contexts would be negatively correlated. An implicit assumption behind this view is that when agricultural conditions are favourable a farm household is more productive on the farm, resorting to off-farm employment only as a hedge against an adverse consumption shock.

More recently, however, researchers have concluded that, on account of various "push" and "pull” factors in poor countries, the diversification of farm households into both 
on-farm and off-farm employment is the norm (Barrett, Reardon and Webb, 2001). For example, in multi-member households with weak land endowments and low marginal productivity of labor in on-farm work, there would be an incentive (or push) to allocate part of the household's labor into off-farm activities. At the same time, there might be other factors, including wage premiums for education, and risk-reduction, "pulling” at least some farm household members into off-farm employment. ${ }^{1}$ These studies find a positive or zero instead of a negative correlation between agricultural income and off-farm participation (Alderman and Paxson, 1992; Reardon et al., 1992, 1998; Reardon, 1997; Barrett et al., 2000). The absence of correlation could imply that off-farm employment for a farm household could be an ex ante risk-reduction strategy instead of only an ex post reaction to low farm income, and that diversification could be a norm instead of only an occasional adjustment to shocks. A positive correlation could reflect entry barriers that poor households may be less able to overcome than wealthy ones (Barrett, Reardon and Webb, 2001).

Such entry barriers, in turn, could be attributed to the transactions costs associated with information, travel, and other limitations on worker mobility as well as the lack of demand for such workers in off-farm work relative to the often downwardly rigid off-farm wage rates. This rationale is consistent not only with the potentially positive correlation between farm income and incidence of off-farm employment but also with other, relatively standard treatments of entitlement failure (e.g., Dasgupta and Ray, 1986; Dasgupta, 1993). ${ }^{2}$

Of course, diversification could in principle be accomplished through asset diversification, e.g., between land and financial assets, thereby rendering diversification through labor allocations an only second best strategy. However, since well-functioning land and capital markets are often absent in developing countries, in practice conversions of some land holdings into financial assets (with returns commensurate with risk) may not be feasible, making the second-best option the only feasible strategy.

\footnotetext{
${ }^{1}$ Evidently, these "push" and "pull" factors implicitly capture some elements of the neoclassical view of offfarm labor supply. However, unlike neoclassical researchers of off-farm employment, researchers who propose the view that diversification of earnings sources is the norm for farm households are not interested in individuallevel decisions, nor in the intra-household decision-making process involving allocation of labor across farm and off-farm activities. They treat the household as the unit of analysis, an idea that also found favour with the neoclassical approach of Rosenzweig (1980).

${ }^{2}$ It should be noted that such transactions costs are generally not observable, and their presence have to be inferred from the impact of factors like non-labor source of income on the likelihood and extent of entitlement failure in the labor market. For example, if farm income or asset income are found to be positively correlated with the likelihood of finding employment in the off-farm sector, a plausible interpretation of the result would be that there are not insignificant costs associated with entry into the off-farm labor market, and that individuals or households with a non-labor source of income is better able to defray these costs than others.
} 
When viewed from the entry barriers and diversification-as-norm perspectives, offfarm employment of farm households provides a litmus test of the existence and quality of market-supporting institutions in the country under study. In a country where markets function reasonably well, workers in each skill category should be able to realize their desired amount of off-farm labor supply at the equilibrium wage rate without interference from the barriers created by transaction costs and market failures. But, in a country in which such market failures are pervasive as in sub-Saharan Africa, size of farm (and hence farm income) might well be positively correlated with the ability to find and obtain off-farm jobs and income. Better endowed households in such countries would be likely to experience lower income and consumption shocks than more poorly endowed ones. As a result, the correlation between farm size and income on the one hand and off-farm jobs and income on the other may provide important insights into prevailing institutional conditions as well as the prospects for income growth and asset inequality in the medium to long term.

It is hardly surprising, therefore, that in Africa, where the quantity and quality of human capital are perhaps too weak for absorption into the non-farm sector, and marketsupporting institutions are often absent, entitlement failures in the market for off-farm labor are pervasive, and inversely related to household wealth (Barrett, Reardon and Webb, 2001). But, are ex ante diversification strategies common and do such entitlement failures exist in more advanced countries where human capital is well developed and income and wealth were less unequal? If the answer should be positive, these concepts of diversification as a norm, entitlement failure and the transaction cost-based barriers to entry could be considerably more important and more generally applicable than existing literature suggests.

In this paper, we attempt to empirically determine whether or not labor market imperfections and failures for certain types of individuals and households such as have frequently been demonstrated for African countries can be found in transition Bulgaria of the 1990s.. While in many respects, e.g., GDP per capita, human capital, and the initial distribution of endowments such as land and property, civil unrest, and the existence of banks, labor laws, and market rules, Bulgaria of the 1990s was very different from Africa, in other respects (incomplete property rights, redundancy of acquired skills, poorly functioning agricultural cooperatives, and incomplete credit, insurance and factor markets), it was somewhat similar.

This is an objective somewhat akin to that of Rizov and Swinnen (2004) for Hungary. In their impressive study Rizov and Swinnen used data from a single survey of farm households to test for the existence of market imperfections in the labor and credit markets, 
finding evidence for both. They show that households with less favourable characteristics and locations are rationed out of the off-farm labor market than their better endowed compatriots. These factors, however, would seem to be rather constant over time. What Rizov and Swinnen did not do was to examine the extent to which these imperfections and the resulting labor supply patterns would change over time with the rapidly changing environmental conditions typical of transition countries.

This is precisely where the advantage of Bulgaria and its household surveys taken at three quite different points in time come in. The extent to which these conditions were changing over time in Bulgaria is quite remarkable and offers an extremely rich environment for studying the effects of adjustments at the farm household level to these changes. For example, problems in the restitution of land were especially prominent early in the transition, the absence of credit and malfunctioning capital markets were especially important in the aftermath of the financial crisis of 1996-97, and the redundancy of acquired skills (especially the kind of education that prevailed during the socialist period) became most serious only after much of the economy had been privatized at the end of the 1990s. In addition, subsequent to the aforementioned crisis, there was a sharp decrease in the demand for all kinds of labor. There were also important changes over time in the degree of labor market imperfections $^{3}$ and barriers to the employment of workers of non-Bulgarian ethnicity, in the latter case especially after privatization (Falaris, 2004).

Our results indicate that off-farm labor supply by Bulgarian farm households was indeed affected by push factors such as the number of adults in the household, and pull factors such as the human capital endowment of these households. In addition, we find evidence of vicious and virtuous circles in post-crisis years, in which people with certain types of education entering the off-farm labor market with greater ease than others. Our results are also consistent with the proposition that diversification is the norm; in most of the years of analysis, the level of agricultural income of farm households did not have any impact on the likelihoods (and levels) of off-farm labor supply. Finally, in keeping with our expectations, the relative roles of push and pull factors in determining the incidence and extent of off-farm labor supply by farm households changed significantly between 1995, 1997 and 2001, the survey years that were marked by very different macroeconomic, institutional and risk environments. Overall, we find evidence that many of the conclusions

\footnotetext{
${ }^{3}$ For example, as the ownership and size of firms changed this affected the extent to which Bulgarian workers and firms would be able to restrict employment and share the rents of these product and other market imperfections (Dobbelaere, 2004)
} 
about off-farm labor supply in very poor African countries summarised in Barrett, Reardon and Webb (2001) can be generalized well beyond the borders of poor countries with underdeveloped institutions and extreme political instability where the need for ex ante diversification might be greater and entitlement failures in the labor markets more expected. These generalisations have potentially important policy implications.

The rest of the paper is organised as follows: In Section 2, we describe the salient macroeconomic and institutional features of the transition process in Bulgaria, their changes over time and the implications thereof for household behaviour in labor markets. In Section 3, we develop an empirical strategy and specification for the analysis of off-farm employment in transition Bulgaria. In Section 4, we describe the data, and use it to highlight the trends in some of the characteristics of Bulgaria's farm households during the 1995-2001 period. The regression results are discussed in Section 5, and Section 6 concludes.

\section{Bulgaria in Transition during the 1990s}

As already mentioned, Bulgaria constitutes a rather ideal case both for comparing offfarm labor supply behaviour with that in developed countries on the one hand and poor, less developed countries on the other. It also serves as an excellent case for examining the effects of changing economic and institutional environments on off-far labor supply.

Indeed, the economic and institutional changes that it underwent were as great as those virtually anywhere else. Following the collapse of socialism and the Council of Mutual Economic Assistance (CMEA) that linked the socialist countries of Central and Eastern Europe in trade, Bulgaria suffered more substantial job loss and economic dislocation than any other country of the region. ${ }^{4}$ Its imports and exports fell by over two-thirds in the early 1990s; unemployment rose from less than 2 percent in 1989 to 16 percent during and immediately after the financial crisis of 1996-97. Hence, between 1989 and 1997, Bulgaria experienced the greatest reductions in GDP, employment, and real wages and the largest increase in the unemployment rate of any of the Central and East European economies (Pauna and Pauna, 1999), before recovering at least partially by 2001.

Several factors contributed to making Bulgaria's response to the dissolution of the CMEA more severe than elsewhere in Eastern Europe. First, prior to its dissolution in 1989, Bulgaria had already been suffering from a deteriorating terms of trade and hence severe

\footnotetext{
${ }^{4}$ Before the CMEA's break-up in 1999, other CMEA countries accounted for over 65 percent of Bulgaria's trade, considerably more than for any other CMEA country. Bulgaria's trade was also much more skewed to Russia (50 percent of the total), than any other CMEA economy (Dobrinsky, 2000).
} 
foreign exchange losses. Second, it had been responding to these problems not by restructuring but only by unsustainable international borrowing, which soon led to the country's default on its foreign debt payments (Dobrinsky, 2000). Third, Bulgaria experienced considerable political instability and its government failed to undertake any reform (except the adoption of a fluctuating exchange rate) program prior to 1997. Even as debt service payments were resumed in 1994 and the economy recovered slightly in 1995, the fiscal deficit remained large and was largely monetized, causing inflation rates to rise from their low of 62 percent in 1995 to 123 percent in 1996 and 1083 percent in 1997. With real interest rates negative throughout much of this period, the financial sector was quite repressed. In 1996, the economy plunged into a deep financial crisis, real GDP falling by 10.1 percent in 1996 and another 7 percent in 1997 (Dobrinsky, 2000).

Of special relevance to the labor market is that in addition to the sharply rising unemployment between 1989 and 1997, there was a massive structural shift out of industry. Of the 1.2 million jobs lost between 1989 and 1997, one million were in industry. While total employment in agriculture was stagnant, agriculture's share in employment rose from 18 percent in 1989 to over 26 percent in 1998. This stagnant level of employment in agriculture camouflages the great labor turnover in this sector, with massive numbers dropping out of the sector largely counterbalanced by the many others moving into it. Unemployment rates varied by region but rose over time, at least until 1998. The flexibility of Bulgaria's labor markets were impeded by relatively high mandatory employer contributions to social security, but the rising unemployment rates were primarily due to the drastic restructuring of the economy and financial crises. Because of the financial crises, virtual absence of credit markets, the paucity of financial assets, and the massive changes in the ownership and employment patterns over time, it is not surprising that entitlement failures in the labor markets were widespread.

An important contributor to the massive retirements within agriculture simultaneous with massive inflows of new workers to the sector was the break-up of the country's collective farms in the early to mid-1990s. Many of these lands were reallocated to those with previous ownership claims, but with some of the non-land assets and residual land auctioned off (Kopeva and Noev, 2001; Abrams and Yossifov, 2003). In many cases, these new farming households had little previous experience in agriculture, driven there by their loss of jobs in government and commerce. As a result, the lack of familiarity with farming would push such households to seek off-farm employment. But, with property rights still far from clear and 
future enforcement of such rights extremely uncertain ${ }^{5}$,this raised the incentive of farm families to keep at least some adult members on the farm in order to protect their insecure claims. This could have undermined the normal push and pull factors encouraging off-farm labor supply. Another casualty of the failure to complement the restoration of land to inexperienced private owners by strengthening property rights was the virtual non-existence of land rental and sale markets and severe and inefficient land fragmentation (Kopeva and Noev, 2001; Noev, Swinnen and Vranken, 2004).

It is clear from the above that between 1990 and 2001, the rural areas of Bulgaria were going through some revolutionary institutional changes while facing a number of major economic shocks. All these shocks and changes may have influenced household decisions about on- and off-farm labor supply. Weather shocks were unfavourable in 1995 and 2001 but favourable in 1997. The risks of loss of property were very great in the early years but gradually fell over time, especially after the development of new commercially oriented cooperatives in the late 1990s. While 1995 was a year of temporary reprieve from the long decline in industry, urban employment, real off-farm wages and trade, 1997 was the year of financial crisis and the highest urban unemployment rates. Income from both financial and other non-agricultural assets plummeted in 1997. Despite the favourable agricultural conditions in 1997, these adverse shocks were so large as to raise the poverty rate from 5.5 percent in 1995 to 37 percent in 1997 (World Bank, 2001). It was especially in 1997, therefore, that there was de facto urban-rural migration with unemployed laborers falling back on subsistence agriculture (including livestock rearing) to mitigate the fall in their consumption levels (Sahn et al, 2002; Rutkowski, 1999).

Both welfare and pension schemes were in existence and indeed well developed in both rural and urban areas of Bulgaria throughout the transition period, though in varying degrees of disrepair over time. Social programs, such as those providing care to children and the elderly were disappearing rapidly. While wages were relatively well indexed to cost of living changes during the year of extremely high inflation (1997), pensions and social welfare benefits were not, implying that these benefits would have been much smaller in 1997 than in the other years under study (1995 and 2001).

Other features of the Bulgarian (and other CEE) economy(ies) over the period under study were (1) that the education and health characteristics of (farm) households were relatively high, (2) that their information networks related to job opportunities were relatively

\footnotetext{
${ }^{5}$ This was especially problematic in the case of orchards because tree crops have such a long gestation period and orchards were kept out of the main land restitution and property rights law (Abrams and Yossifov, 2002).
} 
poorly developed, and (3) that the job structure and desired qualifications of jobs were changing very substantially. Hence, different types of education might well have had quite different effects on off- and on-farm labor decisions over time.

Given the well-developed system of social benefits and the high level of education prevailing in Bulgaria, as well as the fact that many (especially older people) were dropping out of the labor force during the crises of the early and middle parts of the transition, one could expect to find evidence of the push and pull factors found in many studies of labor supply in developed countries. Yet, given the magnitude of the unemployment rates over the period studied, the relatively poor information system about job availability, and the underdevelopment of credit markets for financing relocation, one could also expect to see in Bulgaria evidence of barriers to off-farm jobs as in much poorer countries. Finally, due to the various shocks to agriculture, the varying rates of unemployment in the off-farm sector, structural change in the labor market (de-industrialization and privatization), and the only gradually strengthening property rights in land, one could also expect to find some household and individual characteristics the effects of which would might well vary from period to period as environmental conditions varied.

Goodwin and Holt (2002) studied the labor allocations of farm households in Bulgaria. They used the first wave (1995) of the same Bulgarian Integrated Household Survey (BIHS) data we use to claim that, even as early as 1995, off-farm labor supply in Bulgaria seemed to reflect some of the same push and pull patterns with respect to education, the receipt of social benefits and other characteristics as in countries with well developed labor markets. Given that in 1995 (1) the farm sector was perhaps at its lowest point as a result of not only the break-up of collective farms and cooperatives, but also the failure of delays in restoration of land and clarification of property rights, especially in orchards, and (2) the non-agriculture sectors were in a temporary recovery, such a finding may not be too surprising. No attempt, however, was made either to investigate how such responses may have changed during the 1997 crisis or after the reforms of 1997, or to examine the possibilities of the existence and nature of barriers to entry and entitlement failure in labor markets. The primary objective of this study is to carry out such an investigation using all three waves of the BIHS.

\section{Empirical Strategy and Specification}

It is evident from the above discussion that labor supply functions depend heavily on the different characteristics of individuals and households and that the effects of these 
characteristics depend on whether they represent factors of "pull” or "push” or vulnerability to entitlement failure. To anticipate their overall influences, therefore, it is important to identify which kind of influence each such characteristic represents. However, since any such characteristic can represent more than one such factor and the relative importance of these different factors can also be affected by changing institutional and other conditions, this is not an easy task. For example, it may be easy to categorise educational endowments as "pull" factors, and the number of adults in the household as a "push" factor. But, other household characteristics such as youth and old age dependence ratios can be viewed as both "push" factors and factors representing barriers to entry and vulnerability to entitlement failure in the off-farm labor market (by reducing a household member's time-related flexibility). Hence, ambiguities cannot be avoided. Nevertheless, in the remainder of this section, we attempt to categorize these factors into these three types as best we can. We believe that the resulting empirical specification connects the off-farm labor supply of Bulgarian farm households to its possible correlates in such a way as to reflect Bulgaria's rapidly changing conditions.

To begin with, we take into consideration the demographic characteristics of the households, specifically, the mean age of the working age household members, the total number of household members, and the marital status of the household head. To capture the possible effects of gender- and ethnicity-based barriers to entry and/or differences in the degree of aversion to work outside the home, we include both the share of females among working age adults and ethnicity. If these serve as proxies for barriers to entry into the offfarm labor market, we would expect their effects to be negative whereas to the extent they reflect taste differences, the effects could go either way. Trivially, on account of diminishing marginal productivity of (farm) labor, both the probability of supplying off-farm labor and the total number of off-farm labor hours supplied by a household should increase with the total number of working age adults in the household. Hence, we expect this variable to have positive coefficients in both cases. Since a household might be in greater need of cash for both consumption and investment in the farm's growth, and be in a better position to supply labor off-farm if the household head is married, we also include a dummy variable for the head of household being married and expect it to have a positive effect.

Next, we assume that the presence of young children and elderly people within the household would affect the likelihood of the working age adults' participation in the off-farm labor market, as well as the total number of off-farm labor hours supplied by the household. Hence, we include in the off-farm labor supply equation the number of children of 0-6 and 718 years, and the number of elderly (i.e., greater than 60 years). However, it is difficult to 
form an a priori expectation about the signs of the coefficients associated with these variables. On the one hand, in the face of disappearing low cost (or public) care facilities for the children and the elderly household members, working age adults may find it difficult to participate in the off-farm labor market and, even if they do, their ability to supply a large quantity of off-farm labor may be limited. On the other hand, households with children and elderly members may require more cash to pay for their education, health care and other expenses, in the face of decreasing government subsidies for education and health care. Further, while older children and the elderly may be incapable of working off-farm, they may be able to substitute for the on-farm labor of working age household members should the latter find off-farm employment. Hence, from theory alone, the signs of these coefficients remain ambiguous. Taking the demographic characteristics as a whole, the above discussion indicates that these characteristics can serve as either push factors, encouraging off-farm labor supply, or mitigating factors, raising the possibility of entitlement failures.

There are two possible ways to model education. We can either use the mean years of education of the working age adults of a household, in a linear or a quadratic functional form, or we can use a quasi-semiparametric functional form that uses the proportion of working age household members that have different types of education. While both functional forms have been widely used, earlier studies using the BIHS data (e.g., Dimova and Gang, 2004) have indicated that, especially in the post-crisis period, there was a significant increase in the demand for people with higher education. There is no reason to believe that this would not have applied to (off-farm) employment of farm households. Hence, we adopt the quasisemiparametric form for the participation and off-farm labor supply equations. The impact of education on both the likelihood of participation in the off-farm labor market and the total supply of off-farm labor is expected to be positive (Goodwin and Holt, 2002).

While education is an accurate predictor of both employability and earnings potential (in the off-farm sector) in most contexts, in transition Bulgaria the relationship between education and earnings could be expected to have been particularly weak, largely on account of structural changes that rendered many forms of education redundant. Hence, aside from controlling for educational capabilities of the adult members of the farm households, we also control for the wage rate that these household members received (or were likely to receive) in the off-farm sector. However, we have to take into account an important issue when including the wage rate in our probit and Tobit household-level specifications.

Specifically, if we are concerned about the likelihood of observing at least one working age member of a farm household supplying off-farm labor, it would be reasonable to 
assume that the associated pull factor would be the highest wage that the working age members of that household can command in the off-farm labor market. However, if we are concerned about the total supply of off-farm labor by farm households, the wage rates of all working age members would have to be taken into account. We can account for the wage rates of all working age members by using a summary measure of the distribution of intrahousehold wages, namely, the mean value of these wages.

We have to note, however, that wage rates are observed only for individuals who actually supply off-farm labor. It would, therefore, be reasonable to use in our regression specifications for the probit and Tobit equations for off-farm labor supply the maximum and mean value, respectively, of both the observed wages of household members who actually supplied off-farm labor, and the predicted unobserved wages of those who chose not to enter the off-farm market. These latter wages are estimated with the use of the Heckman (1979) two-step method, which accounts for the non-random selection of individuals into employment. For the purpose, we use data on all individuals in the labor force using individual, location and other characteristics as explanatory variables. Our approach is consistent with Nelson (1977) and Rosenzweig (1980).

It is standard to assume that, like education, the wage rate is a "pull” factor that would induce a farm household to sell labor in the off-farm sector. This assumption would be relevant to decisions both to participate in the off-farm market and the number of hours of labor to supply and would imply a positive impact of wages on the probability to supply offfarm labor and the quantity of off-farm labor supplied. In the latter case, however, to the extent that the household faces a subsistence needs constraint, the effect of a higher wage might well be zero or even negative (Dessing, 2002). As a result, in practice, the direction of the wage impact would depend on the trade-off between the relative price and income effects, the tightness of the subsistence constraint, and the strength of the need to diversify income sources.

As noted above, another potentially important determinant of off-farm participation and labor supply of farm households may be productivity on the farm. But this is potentially jointly determined with off-farm labor supply. Rosenzweig (1980) and others have controlled for farm productivity (and hence farm income) using variables like the size of the farm, a dummy variable for irrigation facilities, and regional weather conditions, while others (e.g., Huffman and Lange, 1989) have used an instrumental variables approach to farm income using not only size of farm and farm capital but also proxy measures for productivity of household members. We do something similar as described in detail in Appendix 2 to come 
up with estimates of farm income. From the perspective of developed countries, the expected sign of the farm output variable in these studies should be negative. But, since in the African or other developing country context, agricultural output has been observed to be either unrelated to ${ }^{6}$ or even positively ${ }^{7}$ correlated with off-farm labor supply, we view the direction of this relationship to be one of the key ones to be determined empirically in this study and would not be surprised if its influence changed over time.

We also control for the benefits received by a household, using a dummy variable that takes the value 1 if at least one working age adult in the household receives social security benefits. This variable presumably measures the reservation level of utility of the household members, but it can also be a proxy for other factors like the health status of the recipient household members. In either case, the coefficient of the benefits variable is likely to be negative.

Finally, we control for the location of the households. First, since off-farm employment would be discouraged by the distance to off-farm jobs, we, include in both the participation/selection and the off-farm labor supply equations a dummy variable that takes the value 1 if a household is located in an urban area. ${ }^{8}$ Second, since the demand for off-farm labor may vary significantly across regions in former socialist economies of Central and Eastern Europe on account of Soviet style industrial planning and differential rates of decline across industries, we also control for the region of the household's location (i.e., Sofia, Bourgas, Varna, Lovech, Montana, Plovdiv, Russe, Sofia Region, and Haskovo). Treating Sofia as the omitted one, we include dummy variables for each of the other eight regions in the specifications for the selection and off-farm labor supply equations.

The quantity of labor supplied to off-farm activities, is usually modelled in two different ways. Rizov and Swinnen (2004) among others have used adaptations of the Heckman two-stage process to account for the selection bias associated with off-farm labor supply. In the first stage of the estimation process they account for the determinants of the choice of whether or not to participate in off-farm labor supply. Then, in the second stage,

\footnotetext{
${ }^{6}$ This could result from rather continuous use of an ex ante diversification strategy (Escobal, 2001).

${ }^{7}$ A positive relationship could be the outcome if members of farm households were to use this income to finance the cost of entering the off-farm labor market (e.g., van den Berg and Ruben, 2001). Other sources of such an effect could arise either (1) where asset income would allow those workers with such income to undercut those competitors without it in the labor market (Dasgupta and Ray, 1986), or (2) if the incidence of asset income would reflect the preference of a household to acquire assets and hence to work off-farm in order to acquire those assets (Mishra and Goodwin, 1998).

${ }^{8}$ Note that the household could be physically located in an urban area while the farm land it owns may be in a rural area. We also experimented with other variables such as distance from the closest bank or post-office, but they proved to be insignificant.
} 
this is used to correct for selection bias in determining the quantity of labor supplied. An alternative to this is the approach of Rosenzweig (1980), which uses separate probit and Tobit models, the latter of course allowing for both zero and positive values of off-farm labor supply. $\equiv$ e adopt the separate probit and Tobit model approach of Rosenzweig (1980). ${ }^{10}$ Our specification for off-farm labor participation is the following probit model:

$$
\begin{aligned}
& y^{*}=\alpha^{\prime} x+\varepsilon \\
& z=1, \text { if } y^{*}>0 \\
& z=0, \text { if otherwise }
\end{aligned}
$$

where $y$ is the off-farm labor supply of the household, $z$ is the participation off-farm by some adult in the household, $x$ is a vector of explanatory variables identified above (defined in Table 1) and $\varepsilon$ is the random error term with zero mean and constant variance.. For the total number of hours of off-farm labor supplied by the household we use the following Tobit model:

$$
\begin{aligned}
& y^{*}=\beta^{\prime} x+\varepsilon \\
& y=y^{*}, \text { if } y^{*}>0 \\
& y=0, \text { otherwise }
\end{aligned}
$$

In principle, the determination of the likelihood of off-farm labor participation and the quantity supplied of that labor could be at either the individual or household levels. We choose to do so using the household instead of the individual as the unit of analysis ${ }^{11}$ for the following reasons. First, since land restitution and the limited number of land rentals in Bulgaria benefited rather disproportionately landlords and tenants in the 50-60 age group of the population (Noev, Swinnen and Vranken, 2004), this would imply that most would also have a spouse and children of working age in the household. Hence, an individual analysis of the choices of household heads a la Goodwin and Holt (2002) could be relevant to only a rather limited portion of the age distribution of the Bulgarian population. As indicated in the

\footnotetext{
${ }^{9}$ The strength of the latter approach lies in the fact that it is not hostage to the difficult problem of identifying the model by having to choose variables that would affect the likelihood of a household to participate in the offfarm labor market but not the quantity of such labor supplied. It is, therefore, widely used in similar contexts, e.g., in studies that model private transfers made by some households to other (related) households.

${ }^{10}$ Note that the Tobit approach is consistent with the diversification-as-the-norm paradigm. To recapitulate, according to this paradigm, farm households necessarily want to supply labor to the off-farm market, and their inability to do so is usually on account of mitigating factors that affect the rate or extent of entitlement failure in the off-farm labor market. In other words, in this paradigm, a farm household does not decide whether or not to participate in the off-farm market, followed by the number of hours to supply to this market. We observe offfarm labor supply if (and when) at least one working age member of a farm household is capable of meeting the minimum requirements of the off-farm employers and what we may loosely call the transactions costs of entering the off-farm labor market.

${ }^{11}$ Since Kimhi (1980) and Rizov and Swinnen (2004) have also analyzed these decisions at the household level, we are not alone in this respect.
} 
next section, by focusing on the off-farm behaviour of all working age members of households with access to land, we obtain a rather balanced sample of working age individuals with mean age of 30-35 and thus greatly mitigate the possibility of age-related selection bias. Second, given the large and rapidly changing environmental conditions affecting both on-farm and off-farm activities, the household level would seem to be the appropriate one for achieving an optimal portfolio of labor allocations. Third, cooperative membership, financial assets and agricultural assets are all observable only at the household level and are all variables that might affect the choices of the household as a whole more than those of any particular household member.

While a case might be made to introduce somewhat different specifications of the model for different years, since our main contribution is to take advantage of the changing economic and institutional conditions over the period under study to explain the possibly changing behavioural reactions over time, to maximize comparability in parameter estimates over time, we retain the same specification for all three years of the data.

\section{Data}

Quite fortuitously, the three different waves of the Bulgarian Integrated Household Survey (BIHS) were undertaken in three years of widely varying returns, real wages and institutional conditions, namely, 1995, 1997 and 2001. These three rounds of the BIHS were conducted by Gallup International under the auspices of the Bulgarian Ministry of Labor, the Ministry of Social Affairs and the National Institute of Statistics. The surveys provide detailed information on demographic and family characteristics, employment, income, education and wealth of all household members of about 2500 households. ${ }^{12}$ The sampling procedures used in the surveys ensure that the samples for each of the surveys are representative. ${ }^{13}$ Given our focus on off-farm labor supply of farm households, our sample consists of those individuals in the approximately 600 households that have access to cultivable land used for farm production. ${ }^{14}$ For labor supply decisions we include only individuals of working age, 18-55 for women and 18-60 for men. ${ }^{15}$

\footnotetext{
${ }^{12}$ Specifically, the surveys include information on 2468 households with a total of 7199 members in 1995, 2323 households with 6947 members in 1997 and 2633 households with 7844 members in 2001.

${ }^{13}$ The sampling was done in two stages. In the first stage the survey sample was selected. The listing was organized in the following order: (i) the list of 28 regions, (ii) cities and villages in these regions, (iii) each city and village listed by size. In the second stage the interviewed households were selected with equal probability, provided that they have also been listed by size. One of the objectives of the interviewers was to reduce the number of refusals to fewer than $5 \%$. Each refusal and each substitution had to be verified by a team supervisor.

${ }^{14}$ This procedure is in keeping with Goodwin and Holt (2002). Note that agricultural labor supply in the form of work as an employee of a private farm or cooperative is included in the category of off-farm labor supply, our
} 
All the variables used in the analysis have been identified above and for convenience are also listed and defined in Table 1. Table 1 also presents the descriptive statistics on all variables separately for each of the three rounds of the survey and does so both for two types of farm households, namely those that do and do not supply any off-farm labor. It can easily be seen that the number of off-farm labor hours supplied by an average household fell quite sharply from the relatively favourable year for such labor (1995) to the financial crisis year (1997) but hardly at all after that. As seen in the table, there was a sharp fall in real wages (especially in the median wage) from 1995 to 1997, but a substantial recovery by $2001 .^{16}$ For each year, the maximum wage rate (but neither the mean nor median wage rate) was higher for those households supplying off-farm labor.

As expected, the households that do not supply off-farm labor had fewer working age members, much higher old age dependency rates and somewhat lower youth dependency rates than households that supply off-farm labor. ${ }^{17}$ Although the proportion of females was consistently lower in households supplying off-farm labor, these differences were not statistically significant. But, households supplying off-farm labor have a significantly higher proportion of married heads, suggesting that married heads may actually have a greater incentive, and/or ability, to participate in the off-farm labor market than non-married ones. As expected, non-Bulgarian heads of households appear more frequently among the households with no members working off-farm, and notably more so in the post-reform year 2001 when most of the off-farm jobs were in the private sector.

Consistent with studies of the returns to different types of education over time in Bulgaria, the descriptive statistics in Table 1 also show a growing gap between households

\footnotetext{
category of households with access to land thus being identical to that of self-employed farmers (or members of cooperatives) as in Rizov and Swinnen (2004).

${ }^{15}$ Eighteen is the age of graduation from compulsory secondary education in Bulgaria and hence few, if any individuals are involved in formal employment prior to this age. Prior to 1999, 55 was the official retirement age for women and 60 was the official retirement age for men in Bulgaria. After 1999, to address the population ageing problem, the government initiated a gradual process of increasing the retirement age, indeed by half a year every two years. Since our most recent sample is for 2001, this policy should have no influence on our results.

${ }^{16}$ In calculating the real purchasing power of the nominal wage in levs, we account not only for inflation but also for the revaluation of the lev in 1999 when one "new lev" became equal to 1000 old levs. Note that for all three years there was a substantial gap between the maximum and median potential real wage rates, especially for those households that actually supplied off-farm labor. This supports the validity of our assumption that, for the off-farm participation decision, the maximum of the potential wage rates would be the most relevant measure of wage rate.

${ }^{17}$ This finding for old age dependency is consistent with the more general finding of Rozelle and Swinnen (2004) that industrial restructuring in the transition economies had the effect of pushing large numbers of elderly individuals permanently into subsistence agriculture. The extremely low level of fertility in Bulgaria throughout its transition period accounts for why the youth dependency rates were so very low for both types of households in all three years.
} 
with and without off-farm employment with respect to vocational and higher education but not secondary (or primary) general education. This is a pattern that is often found in the studies of labor supply in developing countries.

The per-adult equivalent farm income reveals an interesting pattern. In 1995, a relatively stable year, the per adult equivalent farm income of households participating in the off-farm labor market exceeded the per adult equivalent farm income of households not participating in the off-farm labor market. According to the above discussion, there could be two explanations for this. (1) Since in 1995 agricultural reform was not complete and the property rights of the recipients of land restitution not yet secure, leaving the farm for employment might substantially increase the risk of agricultural asset loss. (2) The positive relation between farm income and off-farm participation could reflect the Barrett, Reardon and Webb (2001) situation in which farm households with higher farm endowments were in a better position to secure off-farm employment. Yet, in the crisis year 1997 agricultural income (from commercial agriculture) was very low on a per capita basis since agriculture was mostly for subsistence, but somewhat higher in households not participating in the offfarm market. By 2001, however, when property rights were more secure, the agricultural reforms more complete, and an institutional environment less prone to allowing entitlement failure in the labor market, the expected pattern was realized in which the agricultural income of households not participating in the off-farm labor market greatly exceeded (indeed by a factor of ten!) that of those households participating in the off-farm labor market. ${ }^{18}$

As expected, the proportions of households living in urban areas and reporting asset income were higher among households with off-farm employment in all years. The proportions of households receiving government benefits of some type were rather high in all years, and as expected generally higher for those with no off-farm employment. In the latter respect, however, 1997 was an exception in that not only were the shares lower in general but also the shares of those households with off-farm employment reporting benefits were actually higher than those with no off-farm employment. This no doubt was at least in part due to the sharp fall in the value of these benefits in 1997. The sharp difference between the

\footnotetext{
${ }^{18}$ Note also that in 1995 although households with no off-farm employment had larger landholdings, cooperative shares and land in pastures than those with non-farm employment, they also had agricultural assets of lower value. In the crisis year 1997, the gap between the no off-farm and off-farm households in terms of land holdings disappeared while the gap in the values of agricultural asset holdings reached a maximum. While the proportion of land owned by cooperatives was also at a maximum in 1997, subsequently, reforms of cooperatives were such that the land could remain in private hands though increasingly managed by cooperatives.
} 
income from assets and income from benefits patterns, which will be given more attention in the empirical section, suggests that these two sources of non-labor income seem to be playing very different roles in the determination of off-farm labor supply.

These observations are consistent with labor supply patterns changing over time as property rights strengthened, agricultural reforms were undertaken, and both the educational requirements for off-farm jobs and the transaction costs of accessing off-farm jobs were changing. At any point in time, they point to not only the rather consistent pull factors like higher education and wage potential, and push factors like the number of working age individuals in the household or head being married, but also to the presence of barriers to participation, such as non-Bulgarian ethnicity, non-urban location, the proportions of household members aged 0-6 and over 60, and receipt of government benefits. But the influences on the existence of off-farm employment of agricultural income, land, the proportions of land owned by cooperatives and received by restitution, the value of agricultural assets and general secondary education all changed quite substantially over time.

\section{Regression Results}

As noted above, to mitigate the endogeneity problems arising from the use of the wage rate measures and of agricultural income as explanatory variables in our probit and Tobit models of off-farm labor supply, we first undertook two other related exercises. First, we follow Rosenzweig (1980) in estimating the potential off-farm wage rate for all members of all farm households that do not report participation in the market for off-farm labor. Second, as mentioned above, we correct for the possible endogeneity of agricultural income in the probit and Tobit specification using the instrumental variable (IV) technique (Huffman and Lange, 1989). The specifications and results for these estimations are explained in detail in Appendices A1 and A2, respectively.

The regression results for the main equations of interest, the probit equation for offfarm participation (equation 1) and the tobit equation for the number of hours of off-farm employment (equation 2) above, are reported in Tables 2 and 3, respectively.

\subsection{The Likelihood of Off-farm Labor Supply by Farm Households}

Table 2 reports the coefficient estimates for the probit model that captures the impact of characteristics of a farm household on the ability of (and need for) at least one of its working age members to participate in the market for off-farm labor. The significance of the LR chi-square statistic, as well as McFadden’s R-square values reported at the bottom of the 
table indicate that our specification provides a reasonably good fit to the data in all three survey years.

The coefficient estimates indicate that the so-called pull factors mattered more in determining the supply of off-farm labor in Bulgaria than the push factors. For example, in all three years, education was positively correlated with the likelihood of supply of off-farm labor by Bulgarian farm households. The wage rate, too, was positively correlated with the supply of some off-farm labor, albeit only in 2001, by which time real wages had risen to reasonable levels. On the other hand, total number of adults in the household and other demographic characteristics like youth dependency, which, in principle, constitute the push factor, did not have a significant impact on this likelihood. While old age dependency affected the likelihood of off-farm labor supply by household adults significantly, it acted more as a barrier to entering the off-farm labor market than as a push factor.

At the same time, mitigating factors such as location and ability to bear transactions cost had an impact on the likelihood of supplying labor to the off-farm market. For example, in 1995 and 1997, years of economic stagnation and crisis, respectively, an urban household with access to farm land was more likely to supply off-farm labor than its rural counterpart. In 1997, the region of location of the households also had a significant impact on this likelihood, indicating that the probability of entitlement failure varied significantly across regions. This is consistent with significant variation in the unemployment rate across Bulgarian regions in 1997 (see Dimova, 2006). Further, the receipt of asset income and, in 1997, social security benefits had a positive impact on the likelihood of participation in the off-farm labor market, indicating that entering the off-farm labor market was contingent on the ability to bear the associated transactions costs. ${ }^{19}$ The ability to enter the off-farm market was also influenced by ethnicity, albeit only in 2001, which is ironic because structural reforms were expected to link employability more with capability than with characteristics such as ethnicity.

Importantly, in none of the years was farm income significantly related to the likelihood of supplying off-farm labor, indicating that while supply of off-farm labor in Bulgaria may have been influenced by push, pull and mitigating factors, it did not manifest $e x$ post diversification of earnings sources. This is consistent with the evidence from African countries cited by Barrett, Reardon and Webb (2001).

\footnotetext{
${ }^{19}$ The negative effect of the benefits dummy on off-farm labor market participation occurs in 2001, by which time the value of these benefits had at least been partially restored.
} 
Finally, our results suggest that there was significant variation in the impact of the push, pull and mitigating factors on the likelihood of supplying off-farm labor across the years. In the case of mean age, for example, the standard quadratic form of this relationship rising up to some threshold but declining thereafter - is confirmed for all three years. But the net positive impact of age on this likelihood is the strongest for 1997, when the crisis may have increased the likelihood of entitlement failure of younger people, who were less likely to be in managerial positions and thus less able to protect their jobs than older incumbents. Similarly, in 1995, while all three education variables had positive influences on the likelihood of participation in the off-farm market, only general secondary education had a positive and significant effect. But, in the immediate aftermath of the crisis of 1996-97, it was vocational and tertiary education that had the positive and significant effects. By 2001, only vocational education has a positive impact on this likelihood, once again emphasizing the possibility that by the turn of the century employers (by then mostly private) were making a distinction between tertiary education and employable skills.

Some other important changes over time in the impacts on participation in the offfarm labor market are the following: (1) the negative influence of the share of elderly members in the household declined over time, (2) the positive effect of the dummy for the head being married rose over time, (3) the positive effect of the urban dummy fell over time, (4) the negative effect of non-Bulgarian ethnicity rose sharply in 2001. Most of these findings parallel those found in previous tables and for similar reasons suggested there.

Overall, our results indicate that adverse shocks to farm income did not act as an ex post inducement to Bulgarian farm households to look for off-farm employment during its transition process. Instead, the inducement to supply off-farm labor came largely from pull factors like the human capital of the adult household members, and mitigating factors like location and transactions costs that affected the likelihood of entitlement failure in the offfarm sector. In other words, the nature of off-farm labor supply in Bulgaria, and its determinants, bore similarity with off-farm labor supply by farm households in much poorer developing countries in Africa and elsewhere as shown in Barrett, Reardon and Webb (2001). We shall revisit this issue, and the associated policy implications, in our concluding section.

\subsection{The Quantity of Household Labor Supplied to the Off-Farm Market}

Finally, in Table 3, we report the coefficient estimates of the Tobit model that explains inter-household variation in the extent to which working age household members participated in the market for off-farm labor. Recall that the dependent variable is the total 
number of hours of participation reported by all working age household members. The significance levels of individual explanatory variables as well as the LR chi-square statistic suggest that our model is a good fit for the data for all three survey years. The McFadden's R-square value is comparable with Tobit estimates involving similar sample size.

The coefficient estimates suggest that the supply of off-farm labor itself is influenced by both pull and push factors. For example, the number of hours of off-farm labor supplied by farm households is positively affected by education beyond the primary level. In addition, during the post- structural reforms years of 1997 and 2001, the number of hours supplied increases monotonically with the level of education, bringing to the fore the flight of jobs to higher educated and skilled people in the aftermath of the crisis and subsequent restructuring. At the same time, in keeping with our priors, the total number of adult household members, which embodies a push factor (by reducing the marginal productivity of farm activities), is positively correlated with the supply of off-farm labor. Further, higher social security benefits are associated with a reduction in the supply of off-farm labor in both 1995 and 2001, indicating that in so far as the amount of off-farm labor supply is concerned, the absence of social security receivables acts as a push factor. Notably, in 1997, the year in the values of these benefits were so greatly reduced relative to what those who received them might have expected (due to very insufficient indexation for the extremely high inflation rates of 1996 and 1997), this effect was positive (instead of negative), albeit insignificant.

Once again, the mitigating factors that influence entitlement failure in the off-farm labor market were observed to have significant influences on the extent of off-farm labor supply by farm households. Non-Bulgarian ethnicity and location in a rural area adversely affected the amount of labor supply. In 1997, however, non-Bulgarian households were not at a significant disadvantage over Bulgarian households, perhaps because the crisis reduced the employability of all (or most) people, irrespective of their ethnicity. However, during the crisis year, region of location had a significant impact on the amount of off-farm labor supply. The coefficient of the receipt of asset income was positive in all years but much larger and statistically significant only in 1997 . We suggest three plausible reasons for this: (1) given the depth of the crisis and hence the greater barrier to finding off-farm employment in that year, the benefits of asset income in overcoming these barriers would have been greater; (2) real asset income was especially low in this year (relative to what it would be in normal circumstances) making it a push factor; and (3) because of economies of scope between ownership and management of assets and job search, the latter would be easier. 
Note that while in the traditional literature the effect of both government benefits and asset income would be expected to have similar and negative effects on participation in, and supply of off-farm labor, our findings show that the effects of these two sources of non-labor income can be quite different, depending on circumstances. The effects of receipt of benefits were negative and significant in the probit results for 1995 and in the Tobit results for both 1995 and 2001.By contrast, the effects of asset income were positive and significant for all three years in the probit results and for 1997 in the Tobit results. As noted above, we suggest that the explanation for these differences lies in the fact that asset income may play a more positive role in reducing the transaction costs of finding off-farm employment than benefits income. Their effects were similar and positive in 1997 primarily due to the fact that the real values of both were much lower than would have been expected, serving as important push factors.

As in the case of the probit equations, agricultural income played an insignificant role in determining the supply of off-farm labor. While the coefficients themselves were negative, only the coefficient for 1997 was significant, and only at the 10 percent level. In other words, while there is weak support for an ex post diversification of earnings interpretation in the crisis year of 1997, in more normal years, the evidence is more consistent with ex ante diversification.

Overall, we once again find that the Barrett, Reardon and Webb (2001) argument that supply of off-farm labor by farm households is perhaps more than an ex post reaction to adverse shocks to farm income was largely true in the context of transition Bulgaria. The amount of off-farm labor supply was influenced largely by pull and push factors, as well as by mitigating factors that influence the nature and extent of entitlement failure in off-farm labor markets. Finally, there was considerable variation in the way, and the extent to which, these push, pull and mitigating factors affected the amount of off-farm labor supply of Bulgarian farm households across the years. Once again, we shall discuss the implications of these results further in the concluding section.

\section{Conclusions}

Three general conclusions emerge from this study. First, our results for Bulgaria confirm the importance of many of the standard push and pull influences on off-farm labor supply that have been documented in advanced market economies. Among these are the positive push influence of the number of adults of working age, the positive pull influences of higher education, and the generally negative influence of government benefits. These results 
are not surprising given the similarity of Bulgaria to advanced market economies in its high level of education, its household size and its social security system - at least in relation to developing countries.

Second, at the same time, but in this case more surprisingly, in other respects our results are much like those found in very poor developing countries. For example, the lack of correlation between agricultural income and either off-farm labor participation or supply is suggestive of the presence of the ex ante diversification found in poor developing countries (rather than ex post diversification as in much of the literature on consumption-smoothing). Similarly, we find several rather glaring indications of the importance of transaction costs/entitlement failures in off-farm labor markets. These include asset income being positively related to off-farm labor supply, wage rates not being strongly related to off-farm labor supply, and some demographic characteristics like non-Bulgarian ethnicity and higher shares of the elderly being rather consistently associated with lower off-farm labor supply.

Third, we find several notable examples of behavioural patterns that vary quite significantly over time as economic and institutional conditions changed. Chief among these are the sharply declining coefficients of general secondary education in the participation and labor supply equations. These changes were rather clearly the result of economic restructuring both in terms of sectors (de-industrialization) and ownership (privatization). Other important changes that triggered sharp changes in off-farm labor supply response were the financial crisis and associated failure to properly index benefits income that caused both the receipt of benefits and the receipt of asset income to have especially strong positive influences on off-farm labor supply in 1997.

From these and other results in the study some possible policy implications can be derived. First, the background on the agricultural reforms suggests that the Bulgarian transition experience could have been significantly improved had the lands of the old collective farms been allocated in a way that would both get the land in the hands of people who had more experience in farming and provide them with more immediate security of property rights, especially to lands with orchards. If this would not have been possible, a second best approach would have been to early on make the property rights sufficiently complete to cover rights to sell and rent land and to develop credit markets to the extent that inexperienced or inefficient owners could rent or sell their land to potentially efficient nonowners. A probably necessary complement to this would be to develop the financial markets to the extent that those selling land would have safe and profitable outlets for the proceeds of their land sales. 
Second, and of more direct relevance to the off-farm labor market, would be to undertake a variety of policies that might reduce the transactions costs to farm households of accessing this market. Among the possibilities would be: (1) to improve information networks about job availability and skill requirements, (2) to improve transportation system between farm and off-farm employment such as with jitney or min-bus routes of the types that have proven low cost and flexible in many developing countries, (3) to improve the match between the output of the educational system and the job requirements of those activities in which Bulgaria would have genuine comparative advantage.

Third, and again of direct relevance to the off-farm labor markets, would be to lower the payroll taxes on employees, especially for perhaps seasonal employees that would pick up the slack season in Bulgarian agriculture. Policies of this sort would be of special relevance also to developing countries.

Overall, abstracting from the issue of off-farm labor supply by farm households themselves, the main outcome of our empirical exercise is to establish that policies that aim at adding to the human capital stock of developing country populations are unlikely to be a panacea for entitlement failure. In Bulgaria, the high level of human capital relative to developing countries did play a role in influencing the likelihood and amount of off-farm labor supply. But, in the broader scheme of things, factors that influenced the cost of entering the off-farm labor market proved to be just as important. Emphasis should therefore be put on developing institutions that support a wide range of related markets including labor, credit, capital, and land. The long run solution to the problem of entitlement failure may quite possibly lie in the evolution and development of these markets. 


\section{References}

Abrams, Burton A.and Plamen K.Yossifov (2003). The importance of property rights for economic outcomes: Lessons from the transfer of productive assets from collective to private ownership in Bulgarian agriculture. Proceedings of Enterprise in Transition ( $5^{\text {th }}$ international conference), 49-51.

Alderman, Harold and Christina H. Paxson (1992). Do the poor insure? A synthesis of the literature on risk and consumption in developing countries. The World Bank, Washington, D.C.: Policy Research Working Paper 1008.

Barrett, Christopher B., Mesfin Bezuneh, Daniel C. Clay and Thomas Reardon (2000). Heterogeneous constraints, incentives and income diversification strategies in rural Africa. Mimeo, Cornell University, http://ssrn.com/abstract=258371.

Barrett, Christopher B., Thomas Reardon and Patrick Webb (2001) Nonfarm income diversification and household livelihood strategies in rural Africa: Concepts, dynamics and policy implications, Food Policy, 26(4), 315-331.

Benjamin, Dwayne (1992) Household composition, labor markets and labor demand: Testing for separation in agricultural household models. Econometrica, 60, 287-322.

Dasgupta, Partha and Debraj Ray (1986). Inequality as a determinant of malnutrition and unemployment, I, Theory. Economic Journal, 96, 1011-1034.

Dasgupta, Partha (1993). An inquiry into well-being and destitution. Oxford: Oxford University Press.

de Janvry, Alain and Elisabeth Sadoulet (2001). Income strategies among rural households in Mexico: The role of off-farm activities. World Development, 29 (3), 467-480.

Deininger, Klaus and Pedro Olinto (2001). Rural nonfarm employment and income diversification in Columbia. World Development, 29 (3), 455-465.

Dessing, Maryke (2002). Labor supply, the family and poverty: The S-shaped labor supply curve. Journal of Economic Behavior and Organization, 49, 433-458.

Dimova, Ralitza and Ira Gang (2004). Self selection and earnings during volatile transition. IZA, Bonn: Working paper no. 1158.

Dimova, Ralitza (2006). "Monopolistic wages or efficient contracts?. What determined the wageemployment bargain in post-privatization Bulgaria?” Economics of Transition, 14(2), 321-348.

Dobbelaere, Sabian (2004). Ownership, firm size and rent sharing in Bulgaria. Labor Economics 11 (2), 165-189.

Dobrinsky, Rumen (2000). The transition crisis in Bulgaria. Cambridge Journal of Economics, 24, 581-502.

Escobal, Javier (2001). The determinants of nonfarm income diversification in Peru. World Development, 29 (3), 497-508.

Falaris, Evangelos M. (2004). Private and public wages in Bulgaria. Journal of Comparative Economics, 32 (1), 56-72. 
Goodwin, Barry K. and Matthew T. Holt (2002). Parametric and semiparametric modeling of the offfarm labor supply of agrarian households in transition Bulgaria. American Journal of Agricultural Economics, 84, 184-209.

Heckman, James (1979). Sample selection bias as specification error. Econometrica, 47, 153-161.

Huffman, Wallace E. (1980). Farm and off-farm work decisions: The role of human capital. Review of Economics and Statistics, 62 (1), 14-23.

Huffman, Wallace E. and Mark D. Lange (1989). Off-farm work decisions of husbands and wives: Joint decision making. Review of Economics and Statistics, 71 (3), 471-480.

Jacoby, Hanan G. (1993). Shadow wages and peasant family labor supply: An econometric application to the Peruvian Sierra. Review of Economic Studies, 60 (4), 903-921.

Jolliffe, Dean (2004). The impact of education in rural Ghana: Examining household labor allocation and returns on and off the farm. Journal of Development Economics, 73, 287-314.

Kimhi. Ayal (2004). Family consumption and off-farm participation decisions in Israeli farm households. American Journal of Agricultural Economics, 86 (2), 502-512.

Kopeva, Diana and Nivelin Noev (2001). Aspects of land consolidation after the land reform in Bulgaria. In Ieda Osamu (Ed.), The New Structure of the Rural Economy of Post-communist Countries, Slavic Research Center, Hokkaido University, Sapporo, Japan, 2001, pp.123-159.

Lamb, Russell L. (2003). Fertilizer use, risk and off-farm labor markets in the semi-arid tropics of India. American Journal of Agricultural Economics, 85 (2), 359-371.

Lanjouw, Jeane O. and Peter Lanjouw (1995). Rural non-farm employment: A survey, Washington, D.C.: World Bank, Policy Research Working paper 1463.

Lewis, Arthur (1954). Economic development with unlimited supplies of labor. Manchester School, 22 (2), 131-191.

Mishra, Ashok K. and Barry K. Goodwin (1998). Income risk and allocation of labor time: An empirical investigation. Applied Economics, 30, 1549-1555.

Nelson, Forrest D. (1977) Censored regression models with unobserved, stochastic censoring thresholds. Journal of Econometrics, 6, 309-327.

Noev, Nevelin, Swinnen, Johann and Liesbet Vranken (2004). Fragmentation, abandonment and coownership: Transition problems of the Bulgarian market. Quarterly Journal of International Agriculture, 43, 391-408.

Oldenhanna, T. and A. Oskan (2001). Income diversification and entry barriers: Evidence from the Tigray region of Northern Ethiopia. Food Policy, 26, 351-365.

Pauna, Catalin and Bianca Pauna (1999). Output decline labor reallocation in transitional economics: Where does Romania stand? In Christof and Daniel Daiamu (Eds.) Economic Transition in Romania. Proceedings of the Conference "Romania 2000: 10 Years of Transition - Past, Present and Future".

Reardon, Thomas, C. Delgado and P. Matlon (1992). Determinants and effects of income diversification amongst farm households in Burkina Faso, Journal of Development Studies, 28 (2), 264-296. 
Reardon, Thomas (1997). Using evidence of household income diversification to inform study of the rural nonfarm labor market in Africa. World Development, 25 (5), 735-747.

Reardon, T., K. Stamoulis, A. Balisacan, ME Cruz, J. Berdegue, B. Banks. (1998). Rural nonfarm income in developing countries. The State of Food and Agriculture 1998, Rome: Food and Agricultural Organization of the United Nations.

Rizov, Marian and Johan F. M. Swinen (2004). Human capital, market imperfections, and labor reallocation in transition, Journal of Comparative Economics, 32, 745-774.

Rosenzweig, Mark R. (1980). Neoclassical theory and the optimizing peasant: An econometric analysis of market family labor supply in a developing country. Quarterly Journal of Economics, 94 (1), 31-55.

Rozelle, Scott D. and Johan F.M. Swinnen (2004). Success and failure of reform: Insights from the transition and agriculture, Journal of Economic Literature, 42 (2), 404-456.

Rutkowski, Jan (1999). Labor markets and poverty in Bulgaria. The World Bank, Washington, D.C.: Social protection discussion paper no. 9918.

Sahn, David E., Stephen D. Younger and Chad Meyerhoefer (2002). Rural poverty in Bulgaria: Characteristics and trends. Mimeo, College of Human Ecology, Cornell University, Ithaca.

Sumner, Daniel A. (1982). The off-farm labor supply of farmers. American Journal of Agricultural Economics, August, 499-509.

van den Berg, Marrit and Ruerd Ruben (2001). Nonfarm employment and poverty alleviation of rural farm households in Hunduras. World Development, 29 (3), 549-560.

Weersink, Alfons, Charles Nicholson and Jeeveka Weerhewa (1998). Multiple job holdings among dairy farm families in New York and Ontario. Agricultural Economics, 18, 127-143.

Woldenhanna, T. and A. Oskam (2001). Income diversification and entry barriers: Evidence from the Tigray region of northern Ethiopia. Food Policy, 26, 351-365.

World Bank (2001). Bulgaria: The dual challenge of transition and accession. Country study of the Poverty Reduction and Economic Management Unit for Europe and Central Asia Region. 
Table 1

Descriptive statistics

\begin{tabular}{|c|c|c|c|c|c|c|}
\hline & \multicolumn{2}{|c|}{1995} & \multicolumn{2}{|c|}{1997} & \multicolumn{2}{|c|}{2001} \\
\hline & $\begin{array}{c}\text { No off- } \\
\text { farm labor }\end{array}$ & $\begin{array}{l}\text { Off-farm } \\
\text { labor }\end{array}$ & $\begin{array}{l}\text { No off-farm } \\
\text { labor }\end{array}$ & $\begin{array}{l}\text { Off-farm } \\
\text { labor }\end{array}$ & $\begin{array}{c}\text { No off- } \\
\text { farm labor }\end{array}$ & $\begin{array}{l}\text { Off-farm } \\
\text { labor }\end{array}$ \\
\hline $\begin{array}{l}\text { Number of off-farm labor hours } \\
\text { supplied }\end{array}$ & 0 & $\begin{array}{r}296.73 \\
(162.40)\end{array}$ & 0 & $\begin{array}{r}265.49 \\
(133.71)\end{array}$ & 0 & $\begin{array}{r}262.60 \\
(169.67)\end{array}$ \\
\hline \multicolumn{7}{|l|}{ Demographic characteristics } \\
\hline $\begin{array}{l}\text { Mean age of working age } \\
\text { household members (WKAGE) }\end{array}$ & $\begin{array}{l}46.49 \\
(9.90)\end{array}$ & $\begin{array}{l}39.90 \\
(7.45)\end{array}$ & $\begin{array}{r}43.96 \\
(10.02)\end{array}$ & $\begin{array}{l}39.88 \\
(7.06)\end{array}$ & $\begin{array}{r}44.41 \\
(10.30)\end{array}$ & $\begin{array}{l}40.89 \\
(7.84)\end{array}$ \\
\hline $\begin{array}{l}\text { Proportion of household members } \\
\text { in the } 0-6 \text { age group } \\
\text { (HHAGE0T6) }\end{array}$ & $\begin{array}{r}0.05 \\
(0.16)\end{array}$ & $\begin{array}{r}0.11 \\
(0.23)\end{array}$ & $\begin{array}{r}0.06 \\
(0.18)\end{array}$ & $\begin{array}{r}0.09 \\
(0.20)\end{array}$ & $\begin{array}{r}0.07 \\
(0.20)\end{array}$ & $\begin{array}{r}0.08 \\
(0.17)\end{array}$ \\
\hline $\begin{array}{l}\text { Proportion of household members } \\
\text { in the } 7-18 \text { age group } \\
\text { (HHAGE7T18) }\end{array}$ & $\begin{array}{r}0.19 \\
(0.39)\end{array}$ & $\begin{array}{r}0.31 \\
(0.42)\end{array}$ & $\begin{array}{r}0.24 \\
(0.47)\end{array}$ & $\begin{array}{r}0.28 \\
(0.39)\end{array}$ & $\begin{array}{r}0.26 \\
(0.44)\end{array}$ & $\begin{array}{r}0.27 \\
(0.41)\end{array}$ \\
\hline $\begin{array}{l}\text { Proportion of household members } \\
\text { older than } 60 \text { (HHAGEGT60) }\end{array}$ & $\begin{array}{r}0.5921 \\
(0.6588)\end{array}$ & $\begin{array}{r}0.2701 \\
(0.4507)\end{array}$ & $\begin{array}{r}0.5333 \\
(0.6511)\end{array}$ & $\begin{array}{r}0.2883 \\
(0.5032)\end{array}$ & $\begin{array}{r}0.5267 \\
(0.6473)\end{array}$ & $\begin{array}{r}0.3232 \\
(0.5152)\end{array}$ \\
\hline $\begin{array}{l}\text { Number of working age } \\
\text { individuals (N_ADULTS) }\end{array}$ & $\begin{array}{r}1.88 \\
(0.98)\end{array}$ & $\begin{array}{r}2.62 \\
(1.05)\end{array}$ & $\begin{array}{r}2.03 \\
(1.09)\end{array}$ & $\begin{array}{r}2.61 \\
(1.01)\end{array}$ & $\begin{array}{r}1.92 \\
(1.03)\end{array}$ & $\begin{array}{r}2.63 \\
(1.11) \\
\end{array}$ \\
\hline $\begin{array}{l}\text { Proportion of females among } \\
\text { working age household members } \\
\text { (PR_FEM) }\end{array}$ & $\begin{array}{r}0.57 \\
(0.35)\end{array}$ & $\begin{array}{r}0.50 \\
(0.21)\end{array}$ & $\begin{array}{r}0.57 \\
(0.32)\end{array}$ & $\begin{array}{r}0.51 \\
(0.25)\end{array}$ & $\begin{array}{r}0.55 \\
(0.34)\end{array}$ & $\begin{array}{r}0.51 \\
(0.22)\end{array}$ \\
\hline $\begin{array}{l}\text { Proportion of household heads } \\
\text { who are married (HEADMARR) }\end{array}$ & $\begin{array}{r}0.77 \\
(0.42) \\
\end{array}$ & $\begin{array}{r}0.86 \\
(0.35) \\
\end{array}$ & $\begin{array}{r}0.51 \\
(0.50) \\
\end{array}$ & $\begin{array}{r}0.70 \\
(0.46) \\
\end{array}$ & $\begin{array}{r}0.52 \\
(0.50) \\
\end{array}$ & $\begin{array}{r}0.70 \\
(0.46) \\
\end{array}$ \\
\hline $\begin{array}{l}\text { Proportion of household heads } \\
\text { with non-Bulgarian ethnicity } \\
\text { (NONBULGAR) }\end{array}$ & $\begin{array}{r}0.21 \\
(0.41)\end{array}$ & $\begin{array}{r}0.13 \\
(0.34)\end{array}$ & $\begin{array}{r}0.20 \\
(0.40)\end{array}$ & $\begin{array}{r}0.15 \\
(0.36)\end{array}$ & $\begin{array}{r}0.31 \\
(0.46)\end{array}$ & $\begin{array}{r}0.12 \\
(0.32)\end{array}$ \\
\hline \multicolumn{7}{|l|}{ Education and wage rates } \\
\hline $\begin{array}{l}\text { Proportion of working age } \\
\text { household members with general } \\
\text { secondary education (PR_GSED) }\end{array}$ & $\begin{array}{r}0.14 \\
(0.31)\end{array}$ & $\begin{array}{r}0.21 \\
(0.30)\end{array}$ & $\begin{array}{r}0.19 \\
(0.33)\end{array}$ & $\begin{array}{r}0.20 \\
(0.30)\end{array}$ & $\begin{array}{r}0.16 \\
(0.31)\end{array}$ & $\begin{array}{r}0.15 \\
(0.27)\end{array}$ \\
\hline $\begin{array}{l}\text { Proportion of working age } \\
\text { household members with } \\
\text { vocational education (PR_VED) }\end{array}$ & $\begin{array}{r}0.21 \\
(0.37)\end{array}$ & $\begin{array}{r}0.37 \\
(0.38)\end{array}$ & $\begin{array}{r}0.25 \\
(0.42)\end{array}$ & $\begin{array}{r}0.41 \\
(0.37)\end{array}$ & $\begin{array}{r}0.29 \\
(0.42)\end{array}$ & $\begin{array}{r}0.51 \\
(0.40)\end{array}$ \\
\hline $\begin{array}{l}\text { Proportion of working age } \\
\text { household members with tertiary } \\
\text { education (PR_UED) }\end{array}$ & $\begin{array}{r}0.04 \\
(0.17)\end{array}$ & $\begin{array}{r}0.09 \\
(0.24)\end{array}$ & $\begin{array}{r}0.04 \\
(0.16)\end{array}$ & $\begin{array}{r}0.12 \\
(0.26)\end{array}$ & $\begin{array}{r}0.03 \\
(0.14)\end{array}$ & $\begin{array}{r}0.08 \\
(0.21)\end{array}$ \\
\hline $\begin{array}{l}\text { Maximum wage earned by any } \\
\text { household member (1995 levs) } \\
\text { (MAXWAGE) }\end{array}$ & $\begin{array}{r}57.83 \\
(15.24)\end{array}$ & $\begin{array}{r}60.02 \\
(17.70)\end{array}$ & $\begin{array}{r}37.55 \\
(18.78)\end{array}$ & $\begin{array}{r}44.02 \\
(32.59)\end{array}$ & $\begin{array}{l}47.05 \\
(8.37)\end{array}$ & $\begin{array}{r}66.82 \\
(86.66)\end{array}$ \\
\hline $\begin{array}{l}\text { Mean wage earned by any } \\
\text { household member (1995 levs) } \\
\text { (MEANWAGE) }\end{array}$ & $\begin{array}{l}47.24 \\
(8.96)\end{array}$ & $\begin{array}{l}46.44 \\
(8.44)\end{array}$ & $\begin{array}{l}25.87 \\
(7.65)\end{array}$ & $\begin{array}{r}24.70 \\
(12.88)\end{array}$ & $\begin{array}{l}40.63 \\
(6.35)\end{array}$ & $\begin{array}{r}39.82 \\
(10.56)\end{array}$ \\
\hline \multicolumn{7}{|l|}{ Farm characteristics } \\
\hline $\begin{array}{l}\text { Monthly farm income per working } \\
\text { age adult (1995 levs) (FARMINC) }\end{array}$ & $\begin{array}{r}6793.63 \\
(17090.91) \\
\end{array}$ & $\begin{array}{r}7945.10 \\
(47295.60) \\
\end{array}$ & $\begin{array}{r}737.51 \\
(1590.87) \\
\end{array}$ & $\begin{array}{r}530.20 \\
(815.96) \\
\end{array}$ & $\begin{array}{r}6869.62 \\
(93163.3) \\
\end{array}$ & $\begin{array}{r}669.56 \\
(3401.62) \\
\end{array}$ \\
\hline Total size of land (LANDSIZE) & $\begin{array}{r}41.40 \\
(472.66) \\
\end{array}$ & $\begin{array}{r}8.56 \\
(42.68) \\
\end{array}$ & $\begin{array}{r}28.77 \\
(85.62) \\
\end{array}$ & $\begin{array}{r}36.49 \\
(145.75) \\
\end{array}$ & $\begin{array}{r}153.44 \\
(2102.33) \\
\end{array}$ & $\begin{array}{r}16.93 \\
(79.11) \\
\end{array}$ \\
\hline $\begin{array}{l}\text { Proportion land owned by } \\
\text { cooperatives (PCOOP) }\end{array}$ & $\begin{array}{r}0.09 \\
(0.27)\end{array}$ & $\begin{array}{r}0.06 \\
(0.22)\end{array}$ & $\begin{array}{r}0.20 \\
(0.37)\end{array}$ & $\begin{array}{r}0.15 \\
(0.32)\end{array}$ & $\begin{array}{r}0.03 \\
(0.15)\end{array}$ & $\begin{array}{r}0.04 \\
(0.19)\end{array}$ \\
\hline $\begin{array}{l}\text { Proportion of land in the form of } \\
\text { orchards (ORCHARD) }\end{array}$ & $\begin{array}{r}0.28 \\
(0.45) \\
\end{array}$ & $\begin{array}{r}0.35 \\
(0.48) \\
\end{array}$ & $\begin{array}{r}0.34 \\
(0.48) \\
\end{array}$ & $\begin{array}{r}0.42 \\
(0.49) \\
\end{array}$ & $\begin{array}{r}0.27 \\
(0.45) \\
\end{array}$ & $\begin{array}{r}0.36 \\
(0.48) \\
\end{array}$ \\
\hline $\begin{array}{l}\text { Proportion of land in the form of } \\
\text { pastures (PASTURE) }\end{array}$ & $\begin{array}{r}0.29 \\
(0.46) \\
\end{array}$ & $\begin{array}{r}0.16 \\
(0.37) \\
\end{array}$ & $\begin{array}{r}0.22 \\
(0.42) \\
\end{array}$ & $\begin{array}{r}0.17 \\
(0.37) \\
\end{array}$ & $\begin{array}{r}0.12 \\
(0.33) \\
\end{array}$ & $\begin{array}{r}0.13 \\
(0.33) \\
\end{array}$ \\
\hline $\begin{array}{l}\text { Proportion of land received by } \\
\text { restitution (RESTITUTED) }\end{array}$ & $\begin{array}{r}0.16 \\
(0.37)\end{array}$ & $\begin{array}{r}0.14 \\
(0.35) \\
\end{array}$ & $\begin{array}{r}0.21 \\
(0.41) \\
\end{array}$ & $\begin{array}{r}0.15 \\
(0.36) \\
\end{array}$ & $\begin{array}{r}0.15 \\
(0.36) \\
\end{array}$ & $\begin{array}{r}0.18 \\
(0.39) \\
\end{array}$ \\
\hline
\end{tabular}




\begin{tabular}{|c|c|c|c|c|c|c|}
\hline $\begin{array}{l}\text { Average resale value of } \\
\text { agricultural assets (AGASSETS) }\end{array}$ & $\begin{array}{r}10347.57 \\
(0.25908 .5)\end{array}$ & $\begin{array}{l}21564.33 \\
(118630)\end{array}$ & $\begin{array}{r}9939.81 \\
(62182.2)\end{array}$ & $\begin{array}{r}26845.9 \\
(136587)\end{array}$ & $\begin{array}{r}13228.2 \\
(65904.7)\end{array}$ & $\begin{array}{l}24759.6 \\
(132042\end{array}$ \\
\hline \multicolumn{7}{|c|}{ Non-farm sources of non-labor income } \\
\hline $\begin{array}{l}\text { Proportion of households reporting } \\
\text { asset income (D_ASSETINC) }{ }^{\mathrm{a}}\end{array}$ & $\begin{array}{r}0.28 \\
(0.45) \\
\end{array}$ & $\begin{array}{r}0.32 \\
(0.47) \\
\end{array}$ & $\begin{array}{r}0.20 \\
(0.40) \\
\end{array}$ & $\begin{array}{r}0.30 \\
(0.46) \\
\end{array}$ & $\begin{array}{r}0.33 \\
(0.47) \\
\end{array}$ & $\begin{array}{r}0.41 \\
(0.49) \\
\end{array}$ \\
\hline $\begin{array}{l}\text { Proportion of household receiving } \\
\text { benefits (D_BENEFITS) })^{\mathrm{a}}\end{array}$ & $\begin{array}{r}0.85 \\
(0.36) \\
\end{array}$ & $\begin{array}{r}0.78 \\
(0.41) \\
\end{array}$ & $\begin{array}{r}0.56 \\
(0.50) \\
\end{array}$ & $\begin{array}{r}0.66 \\
(0.48) \\
\end{array}$ & $\begin{array}{r}0.90 \\
(0.29) \\
\end{array}$ & $\begin{array}{r}0.75 \\
(0.44) \\
\end{array}$ \\
\hline \multicolumn{7}{|l|}{ Location } \\
\hline $\begin{array}{l}\text { Proportion of households located } \\
\text { in urban areas (URBAN) }{ }^{\mathrm{a}}\end{array}$ & $\begin{array}{r}0.25 \\
(0.43)\end{array}$ & $\begin{array}{r}0.51 \\
(0.50)\end{array}$ & $\begin{array}{r}0.38 \\
(0.49) \\
\end{array}$ & $\begin{array}{r}0.54 \\
(0.50)\end{array}$ & $\begin{array}{r}0.24 \\
(0.43)\end{array}$ & $\begin{array}{r}0.44 \\
(0.50) \\
\end{array}$ \\
\hline Number of observations & 189 & 397 & 241 & 389 & 209 & 336 \\
\hline
\end{tabular}

Note: The values within parentheses are standard deviations.

${ }^{a}$ These variables are used in the form of dummies in the regression models whose coefficients are reported in Tables 2 and 3. 
Table 2

Determinants of the likelihood of off-farm labor supply by farm households

\begin{tabular}{|c|c|c|c|c|c|c|c|c|c|}
\hline & \multicolumn{3}{|c|}{1995} & \multicolumn{3}{|c|}{1997} & \multicolumn{3}{|c|}{2001} \\
\hline & Coefficient & & SE & Coefficient & & SE & Coefficient & & SE \\
\hline CONSTANT & -6.69 & $* *$ & 3.27 & -5.24 & $* *$ & 2.29 & -3.05 & $*$ & 1.62 \\
\hline WKAGE & 0.15 & $* *$ & 0.07 & 0.27 & $* * *$ & 0.001 & 0.14 & $* *$ & 0.07 \\
\hline WKAGE $^{2}$ & -0.002 & $* *$ & 0.001 & -0.003 & $* * *$ & 0.001 & -0.002 & $* *$ & 0.001 \\
\hline HHAGE0T6 & 0.55 & & 0.36 & 0.57 & & 0.36 & 0.29 & & 0.40 \\
\hline HHAGE7T18 & 0.22 & & 0.20 & -0.12 & & 0.17 & 0.15 & & 0.18 \\
\hline HHAGEGT60 & -0.34 & $* *$ & 0.16 & -0.29 & $*$ & 0.16 & -0.16 & & 0.16 \\
\hline N_ADULTS & 0.14 & & 0.11 & 0.01 & & 0.09 & 0.27 & $* * *$ & 0.09 \\
\hline PR_FEM & -0.25 & & 0.28 & -0.39 & & 0.22 & 0.06 & & 0.26 \\
\hline HEADMARR & 0.13 & & 0.18 & 0.20 & & 0.16 & 0.33 & $* *$ & 0.17 \\
\hline NONBULGAR & -0.19 & & 0.21 & -0.12 & & 0.18 & -1.04 & $* * *$ & 0.20 \\
\hline PR_GSED & 0.44 & $*$ & 0.25 & 0.31 & & 0.20 & -0.12 & & 0.25 \\
\hline PR_VED & 0.18 & & 0.27 & 0.59 & $* * *$ & 0.17 & 0.54 & $* * *$ & 0.19 \\
\hline PR_UED & 0.02 & & 0.53 & 1.29 & $* * *$ & 0.32 & 0.64 & & 0.44 \\
\hline MAXWAGE & 1.18 & & 0.83 & -0.07 & & 0.22 & 1.12 & $*$ & 0.69 \\
\hline D_BENEFIT & 0.09 & & 0.17 & 0.31 & $* *$ & 0.13 & -0.60 & $* * *$ & 0.19 \\
\hline D_ASSETINC & 0.26 & $*$ & 0.15 & 0.45 & $* * *$ & 0.14 & 0.24 & * & 0.15 \\
\hline FARMINC & -0.03 & & 0.08 & -0.07 & & 0.06 & -0.01 & & 0.01 \\
\hline PCOOP & -0.12 & & 0.22 & -0.18 & & 0.15 & 0.15 & & 0.33 \\
\hline URBAN & 0.31 & $* *$ & 0.16 & 0.27 & $* *$ & 0.13 & 0.01 & & 0.16 \\
\hline Regions & Yes & & & Yes & $* * *$ & & Yes & & \\
\hline Log likelihood & -274.18 & & & -329.44 & & & -263.78 & & \\
\hline Chi-square & 188.53 & $* * *$ & & 179.39 & $* * *$ & & 198.10 & $* * *$ & \\
\hline Pseudo R-square & 0.26 & & & 0.21 & & & 0.27 & & \\
\hline Nobs & 586 & & & 630 & & & 545 & & \\
\hline
\end{tabular}

Note: $\quad$ SE are robust standard errors.

$* * *, * *$ and $*$ indicate significance at $1 \%, 5 \%$ and $10 \%$ levels of significance. 
Table 3

Determinants of amount of off-farm labor supply by farm households

\begin{tabular}{|c|c|c|c|c|c|c|c|c|c|}
\hline & \multicolumn{3}{|c|}{1995} & \multicolumn{3}{|c|}{1997} & \multicolumn{3}{|c|}{2001} \\
\hline & Coefficient & & SE & Coefficient & & SE & Coefficient & & SE \\
\hline CONSTANT & -167.12 & & 386.79 & -1016.90 & & 688.41 & -472.91 & * & 260.87 \\
\hline WKAGE & 25.37 & $* *$ & 11.34 & 45.56 & $* * *$ & 11.23 & 19.11 & $*$ & 11.59 \\
\hline WKAGE $^{2}$ & -0.35 & $* *$ & 0.13 & -0.55 & $* * *$ & 0.13 & -0.24 & $*$ & 0.14 \\
\hline HHAGE0T6 & 20.95 & & 54.85 & 64.41 & & 55.58 & 45.85 & & 62.91 \\
\hline HHAGE7T18 & 6.38 & & 33.94 & -15.34 & & 29.93 & 42.83 & & 29.82 \\
\hline HHAGEGT60 & -54.36 & $* *$ & 25.61 & -49.84 & $*$ & 26.35 & 3.29 & & 25.32 \\
\hline N_ADULTS & & & & & & & & & \\
\hline PR_FEM & -48.95 & & 44.09 & -46.94 & & 37.82 & -48.25 & & 46.91 \\
\hline HEADMARR & 22.38 & & 28.02 & 24.25 & & 24.97 & 45.49 & $*$ & 26.27 \\
\hline NONBULGAR & -64.16 & $* *$ & 32.48 & -14.80 & & 29.03 & -170.85 & $* * *$ & 34.26 \\
\hline PR_GSED & 113.25 & $* * *$ & 36.88 & 81.48 & $* *$ & 35.58 & 84.57 & $* *$ & 40.85 \\
\hline PR_VED & 92.68 & $* * *$ & 34.13 & 110.97 & $* * *$ & 33.23 & 135.35 & $* * *$ & 30.95 \\
\hline PR_UED & 103.88 & $*$ & 58.43 & 199.43 & $* * *$ & 50.16 & 177.95 & $* * *$ & 66.79 \\
\hline MAXWAGE & -39.03 & & 96.25 & 7.50 & & 11.23 & -19.14 & & 133.71 \\
\hline D_BENEFIT & -64.99 & $* *$ & 26.26 & 28.96 & & 20.59 & -89.70 & $* * *$ & 26.27 \\
\hline D_ASSETINC & 34.05 & & 21.54 & 71.46 & $* * *$ & 20.78 & 19.84 & & 22.31 \\
\hline FARMINC & -16.40 & & 12.44 & -16.52 & $*$ & 9.22 & -1.26 & & 2.18 \\
\hline PCOOP & -49.18 & & 33.77 & - 24.69 & & 23.51 & 47.89 & & 49.09 \\
\hline URBAN & 58.75 & $* * *$ & 22.16 & 47.06 & $* *$ & 22.13 & 36.68 & & 23.45 \\
\hline Regions & Yes & & & Yes & $*$ & & Yes & $*$ & \\
\hline$\Sigma$ & 207.33 & & 7.84 & 202.1641 & & 7.8601 & 206.4894 & & 8.4841 \\
\hline Log likelihood & -2817.30 & & & -2788.29 & & & -2400.44 & & \\
\hline Chi-square & 269.29 & $* * *$ & & 229.00 & $* * *$ & & 264.59 & $* * *$ & \\
\hline Pseudo R-square & 0.0456 & & & 0.0394 & & & 0.0522 & & \\
\hline Nobs & 586 & & & 630 & & & 545 & & \\
\hline
\end{tabular}




\section{Appendix 1}

As indicated in Section 3, our probit and Tobit specifications account for the potentially important impact of the maximum and mean wages of household members supplying off-farm labor and the predicted maximum and mean wages of household members not supplying off-farm labor. These latter wages are estimated with the use of the two-stage Heckman selection model based on data for all working age individuals in each survey year. In the first step, we estimate a labor force participation equation, which explains how individual characteristics and other exogenous factors influence the likelihood of an individual to sustain employment. In the second stage, the wage equations are estimated after accounting for potential selection bias and the coefficients for the wage equation are then used to generate predicted values of the wages of those that do not report employment.

. In keeping with the literature (Rosenzweig, 1980; Killingsworth and Heckman, 1986; Huffman and Lange, 1989) we argue that the participation of an individual in the offfarm market is influenced by her own characteristics, as well as those of the household to which she belongs. Specifically, it depends nonlinearly on her age and years of education, and linearly on gender, marital status and ethnicity. It also depends on whether the relevant household has access to farmland, and the age distribution of the households. Participation is likely to be hindered by the presence of young children in the household and elderly people who need care, especially if the worker is female (Lundberg, 1988; Pezzin and Schone, 1999). But presence of non-adult children of the intermediate age group (7-18), who can help their parents take care of household chores, or work on the family farm, can facilitate labor market participation. The participation equation, therefore, is as follows:

$$
\begin{aligned}
\text { PARTICIPATE } & =\beta_{0}+\beta_{1} \text { AGE }+\beta_{2} \text { AGE }^{2}+\beta_{3} \text { YREDUC }+\beta_{4} \text { YREDUC }^{2} \\
& +\beta_{5} \text { FEMALE }+\beta_{6} \text { MARRIED }+\beta_{7} \text { NONBULGAR } \\
& +\beta_{8} \text { ACSLAND }+\beta_{9} \text { HHAGE0T6 }+\beta_{10} \text { HHAGE7T18 } \\
+ & \beta_{11} \text { HHAGEGT60 }+\beta_{12}(\text { FEMALE } \times \text { HHAGE0T6 }) \\
& +\beta_{13}(\text { FEMALE } \times \text { HHAGE7T18 })+\beta_{14}(\text { FEMALE } \times \\
& \text { HHAGEGT60 })+u_{1}
\end{aligned}
$$

The wage rate itself, depends largely on the characteristics (or capabilities) of the relevant individual, namely, age, gender, ethnicity and education. There is evidence that in transition economies like Bulgaria returns to education vary significantly across types of education-vocational, secondary and tertiary (Dimova and Gang, 2004). Hence, we include in the wage equation the type of education, with primary education as the omitted category, as opposed to a quadratic function of the number of years of education. Finally, in keeping with 
the literature that suggests that the Bulgarian labor market was relatively fragmented during the period of transition (Dimova, 2006), we control for the location of an individual laborer using regional controls, as well as a dummy variable that takes the value unity when the laborer is located in an urban area. The omitted category for the regional control is Sofia, the capital city, which accounts for about one eighth of the population. The wage equation, therefore, is as follows:

$$
\begin{aligned}
\text { WAGE }=\gamma_{0}+ & \gamma_{1} \text { AGE }+\gamma_{2} \text { AGE }^{2}+\gamma_{3} \text { FEMALE }+\gamma_{4} \text { NONBULGAR } \\
& +\gamma_{5} \text { SECONDARY }+\gamma_{6}{\text { VOCATIONAL }+\gamma_{7} \text { TERTIARY }} \\
& +\gamma_{8} \text { URBAN }+\Sigma_{\mathrm{i}} \gamma_{9 \mathrm{i}} \text { REGION }_{\mathrm{i}}+\mathrm{u}_{2}
\end{aligned}
$$

Experimentation with our explanatory variables indicates that the dependency ratios used in the first stage equation are not significant in the second stage equation, thus confirming their appropriateness as excluding conditions in our system of equations. We use the maximum likelihood methodology to jointly estimate these equations.

The coefficient estimates are reported in Table A1. The top part of the table gives the MLE parameter estimates of the (off-farm) wage equation while the bottom part reports the results of the selection equation. In the former part, there are a number of determinants that have very consistent effects over the years. In particular, the dummy for female gender has consistently negative and significant effects, general secondary, vocational and especially tertiary education all have positive and significant effects. These results are consistent with previous labor market studies on Bulgaria (Falaris, 2004; Dimova and Gang, 2004).

But there are also some notable differences across years. Non-Bulgarian ethnicity has a significant negative effect only in 1995, and age (reflecting experience) has the expected positive but then declining influence only in that year. In the crisis year 1997 age has a negative (but subsequently increasing) effect, perhaps reflecting the advantage of youth (and mobility) in such a difficult year. The urban dummy variable has a positive influence only in the pre-reform and relatively prosperous year 1995 where relatively high-paying jobs in state enterprises were still available for at least some farm households. Even the magnitudes of the coefficients of the education variables show considerable variation over time, those for secondary and vocational education being higher in the crisis year 1997 and that of tertiary education being lowest in that year.

In the selection equation at the bottom of Table A1, age has the expected significant concave impact in all three years with a maximum value at around 40 years of age, while female gender and non-Bulgarian ethnicity have the expected negative impacts on labor force 
participation. At the same time, some of the coefficients reflect significant differences over time. While in 1995 education has a linear positive impact on labor force participation, in 1997 and 2001 its impact is concave indicating the increasing redundancy of higher education acquired in the socialist era in the process of structural reform. The impact of urban location falls over time; the effect of the married dummy has a statistically significant positive influence only in 1995; and the negative influences of the proportions of household members in the $0-6$ for females rises over time. Since the results of this table are somewhat peripheral to our analysis, in the interest of space, we choose not to go into detail about them. Nevertheless, the interested reader should easily be able to come up with explanations for some of them based on foreseen effects of the various important changes over time identified in Section 2. ${ }^{20}$

Overall, the estimates for both steps of the wage regression are meaningful, and are consistent with earlier results reported by research undertaken in the context of Bulgaria, and other transition/developing country labor markets (e.g., Dimova and Gang, 2004). Notice also that the selection equation is not redundant, as indicated by the significance of the test for rho at the bottom of the table.

\footnotetext{
${ }^{20}$ Examples include the growing importance of higher education and hence the negative effect of the proportion of members 7-18 in the household, the stronger negative effect of non-Bulgarian ethnicity in 2001 when most off-farm jobs were in the private sector and the strongest negative impact of old age dependency on the labor supply of working age household members during the crisis which had a disproportionately negative impact on the health and welfare of elderly individuals in Bulgaria.
} 
Table A1

Determinants of (off-farm) wage

\begin{tabular}{|c|c|c|c|}
\hline & 1995 & 1997 & 2001 \\
\hline \multicolumn{4}{|c|}{$\begin{array}{l}\text { Wage equation } \\
\text { Dependent variable: Log wage rate }\end{array}$} \\
\hline Constant & $\begin{array}{l}3.0156 * * * \\
(0.2794)\end{array}$ & $\begin{array}{l}7.3496 * * * \\
(0.4715)\end{array}$ & $\begin{array}{l}0.5484 \\
(0.3699)\end{array}$ \\
\hline AGE & $\begin{array}{l}0.0287 * * \\
(0.0124)\end{array}$ & $\begin{array}{l}-0.0482 * * \\
(0.0188)\end{array}$ & $\begin{array}{c}-0.0041 \\
(0.0154)\end{array}$ \\
\hline $\mathrm{AGE}^{2}$ & $\begin{array}{r}-0.0003^{*} \\
(0.0002)\end{array}$ & $\begin{array}{l}0.0007^{* * *} \\
(0.0002)\end{array}$ & $\begin{array}{l}0.0001 \\
(0.0002)\end{array}$ \\
\hline FEMALE & $\begin{array}{l}-0.2919 * * * \\
(0.0276)\end{array}$ & $\begin{array}{l}-0.2565 * * * \\
(0.0484)\end{array}$ & $\begin{array}{l}-0.2539 * * * \\
(0.0357)\end{array}$ \\
\hline NONBULGAR & $\begin{array}{l}-0.1157^{* *} \\
(0.0529)\end{array}$ & $\begin{array}{l}0.0412 \\
(0.0963)\end{array}$ & $\begin{array}{l}0.0134 \\
(0.0727)\end{array}$ \\
\hline SECONDARY & $\begin{array}{l}0.1113^{* *} \\
(0.0449)\end{array}$ & $\begin{array}{l}0.2159 * * \\
(0.0856)\end{array}$ & $\begin{array}{l}0.1169 * \\
(0.0637)\end{array}$ \\
\hline VOCATIONAL & $\begin{array}{l}0.2239 * * * \\
(0.0410)\end{array}$ & $\begin{array}{l}0.2961 * * * \\
(0.0776)\end{array}$ & $\begin{array}{l}0.1625 * * * \\
(0.0566)\end{array}$ \\
\hline TERTIARY & $\begin{array}{l}0.4987 * * * \\
(0.0510)\end{array}$ & $\begin{array}{l}0.4323 * * * \\
(0.0951)\end{array}$ & $\begin{array}{l}0.4777 * * * \\
(0.0699)\end{array}$ \\
\hline URBAN & $\begin{array}{l}0.0740 * * \\
(0.0348)\end{array}$ & $\begin{array}{l}0.1032 \\
(0.0664)\end{array}$ & $\begin{array}{l}0.0661 \\
(0.0455)\end{array}$ \\
\hline Region & Yes *** & Yes $* * *$ & Yes $* * *$ \\
\hline \multicolumn{4}{|c|}{$\begin{array}{l}\text { Selection equation } \\
\text { Dependent variable: Dummy=1 if individual was observed to have paid } \\
\text { employment in the off-farm sector }\end{array}$} \\
\hline Constant & $\begin{array}{c}-4.4070 * * * \\
(0.2708)\end{array}$ & $\begin{array}{l}-4.8170 * * * \\
(0.2913)\end{array}$ & $\begin{array}{l}-4.9207 * * * \\
(0.2754)\end{array}$ \\
\hline AGE & $\begin{array}{l}0.2132 * * * \\
(0.0105)\end{array}$ & $\begin{array}{l}0.1710^{* * *} \\
(0.0102)\end{array}$ & $\begin{array}{l}0.1842 * * * \\
(0.0109)\end{array}$ \\
\hline $\mathrm{AGE}^{2}$ & $\begin{array}{l}-0.0027 * * * \\
(0.0001)\end{array}$ & $\begin{array}{l}-0.0021 * * * \\
(0.0001)\end{array}$ & $\begin{array}{c}-0.0024 * * * \\
(0.0001)\end{array}$ \\
\hline YREDUC & $\begin{array}{l}0.0573 * * \\
(0.0257)\end{array}$ & $\begin{array}{l}0.1604 * * * \\
(0.0332)\end{array}$ & $\begin{array}{l}0.1548 * * * \\
(0.0293)\end{array}$ \\
\hline YREDUC $^{2}$ & $\begin{array}{c}-0.0007 \\
(0.0012)\end{array}$ & $\begin{array}{c}-0.0039 \text { *** } \\
(0.0014)\end{array}$ & $\begin{array}{c}-0.0036 \text { *** } \\
(0.0012)\end{array}$ \\
\hline FEMALE & $\begin{array}{c}-0.2047 * * * \\
(0.0706)\end{array}$ & $\begin{array}{c}-0.1415 * * \\
(0.0678)\end{array}$ & $\begin{array}{c}-0.1871 \text { *** } \\
(0.0633)\end{array}$ \\
\hline MARRIED & $\begin{array}{l}0.1567 \text { *** } \\
(0.0567)\end{array}$ & $\begin{array}{l}0.0835 \\
(0.0538)\end{array}$ & $\begin{array}{l}0.0610 \\
(0.0497)\end{array}$ \\
\hline NONBULGAR & $\begin{array}{c}-0.3525 * * * \\
(0.0709)\end{array}$ & $\begin{array}{c}-0.3027 \text { *** } \\
(0.0739)\end{array}$ & $\begin{array}{c}-0.4381 * * * \\
(0.0676)\end{array}$ \\
\hline ACSLAND & $\begin{array}{c}-0.0262 \\
(0.0483)\end{array}$ & $\begin{array}{c}-0.0540 \\
(0.0474)\end{array}$ & $\begin{array}{l}0.0720 \\
(0.0505)\end{array}$ \\
\hline HHAGE0T6 & $\begin{array}{c}-0.0316 \\
(0.0736)\end{array}$ & $\begin{array}{l}0.0678 \\
(0.0734)\end{array}$ & $\begin{array}{c}-0.0378 \\
(0.0687)\end{array}$ \\
\hline HHAGE7T18 & $\begin{array}{c}-0.0643 \\
(0.0620)\end{array}$ & $\begin{array}{c}-0.0435 \\
(0.0612)\end{array}$ & $\begin{array}{c}-0.1708 \text { *** } \\
(0.0587)\end{array}$ \\
\hline HHAGEGT60 & $\begin{array}{r}-0.0396 \\
(0.0665)\end{array}$ & $\begin{array}{c}-0.2972 * * * \\
(0.0634)\end{array}$ & $\begin{array}{r}-0.1075 * \\
(0.0622)\end{array}$ \\
\hline
\end{tabular}




\begin{tabular}{|l|l|l|l|}
\hline FEMALE $\times$ HHAGE0T6 & $-\begin{array}{l}-0.1650 * \\
(0.0991)\end{array}$ & $\begin{array}{l}-0.1755^{*} \\
(0.1000)\end{array}$ & $\begin{array}{l}-0.2658^{* * *} \\
(0.0955)\end{array}$ \\
\hline FEMALE $\times$ HHAGE7T18 & 0.1314 & 0.0972 & $0.1838^{* *}$ \\
& $(0.0845)$ & $(0.0836)$ & $(0.0792)$ \\
\hline FEMALE $\times$ HHAGEGT60 & $-0.1782 * *$ & -0.0766 & 0.0142 \\
& $(0.0899)$ & $(0.0874)$ & $(0.0846)$ \\
\hline URBAN & $0.2413^{* * *}$ & $0.2448 * * *$ & $0.1801 * * *$ \\
& $(0.0544)$ & $(0.0566)$ & $(0.0540)$ \\
\hline Regions & Yes *** & Yes *** & Yes *** \\
\hline \multicolumn{3}{|l|}{} \\
\hline Rho & -0.1370 & -0.5760 & -0.4238 \\
& $(0.1002)$ & $(0.0769)$ & $(0.0948)$ \\
\hline Sigma & 0.5740 & 0.9940 & 0.7178 \\
& $(0.0103)$ & $(0.0391)$ & $(0.0251)$ \\
\hline Lambda & 0.0786 & -0.5725 & -0.3042 \\
& $(0.0582)$ & $(0.0971)$ & $(0.0774)$ \\
\hline LR test indep eq (rho $=0)$ & 1.50 & 11.00 & 9.13 \\
Prob>chisq & $(0.2211)$ & $(0.0009)$ & $(0.0025)$ \\
\hline $\mathrm{R}^{2}$ & 0.2304 & 0.1662 & 0.2021 \\
\hline N observations & 5749 & 5644 & 6543 \\
\hline
\end{tabular}

Notes: The figures within parentheses are robust standard errors.

$* * *, * *$ and $*$ indicate significance at $1 \%, 5 \%$ and $10 \%$ levels, respectively. 


\section{Appendix 2}

\section{Instrumenting agricultural income}

Following Huffman (1980) we specify agricultural income earned by a farm household to depend on the characteristics of both the household members and the land and agricultural assets at the disposal of the household. Among the characteristics of household members we include mean age (and age square), the proportions of the household members of working age that are female, the youth and elderly dependence ratios, the proportion of individuals with general secondary, vocation and higher education and a dummy variable for whether or not the household head is married. The characteristics of land include the amount of owned land, the value of agricultural assets, the proportions of owned land obtained in the process of restitution, land in orchards and pastures, and the interactions of the different types of land with the region dummy variables.

The specification for the model that explains variations in agricultural income across farms, therefore, is as follows:

$$
\begin{aligned}
\text { AGINC }=\delta_{0}+ & \delta_{1} \text { AGEH }+\delta_{2} \text { AGEH } 2+\delta_{3} \text { FEMALEH } \\
& +\delta_{4} \text { SECONDARYH }+\delta_{5} \text { VOCATIONALH } \\
& +\delta_{6} \text { TERTIARYH }+\delta_{7} \text { HHAGE0T6 }+\delta_{8} \text { HHAGE7T18 } \\
& +\delta_{9} \text { HHAGEGT60 }+\delta_{10} \text { HMARRIED }+\delta_{11} \text { LANDSIZE } \\
& +\delta_{12} \text { PCOOP }+\delta_{13} \text { ORCHARD }+\delta_{14} \text { PASTURE } \\
& +\delta_{15} \text { RESTITUTED }+\delta_{16} \text { AGASSETS }+\Sigma_{\mathrm{i}} \delta_{7 \mathrm{i}} \text { REGION }_{\mathrm{i}} \\
& +\Sigma_{\mathrm{i}} \delta_{8 \mathrm{i}}\left(\text { REGION }_{\mathrm{i}} \times \mathrm{LANDSIZE}\right) \\
& +\Sigma_{\mathrm{i}} \delta_{9 \mathrm{i}}\left(\mathrm{REGION}_{\mathrm{i}} \times \mathrm{ORCHARD}\right) \\
& +\Sigma_{\mathrm{i}} \delta_{10 \mathrm{i}}\left(\mathrm{REGION}_{\mathrm{i}} \times \mathrm{PASTURE}\right)+\mathrm{u}_{3}
\end{aligned}
$$

We estimate this model using ordinary least squares (OLS), and correct for heteroskedasticity such that the resultant standard errors are robust.

The coefficient estimates are reported in Table A2. It is evident from the results reported in the table that very few of the characteristics of household members have significant effects on the agricultural income of farm households. In 2001, none of these variables has a statistically significant effect. In 1995, the only one that seems to have affected agricultural or farm income is the share of household members with tertiary education and its effect is negative, perhaps suggesting that higher education induces household members to devote more time to off-farm activities than to on-farm ones. Alternatively, people with tertiary education may be particularly unsuitable for farm work. 
This negative effect is equally strong in 1997. But in 1997, there is an additional household characteristic variable that is significant, the share of household members in the 7-18 age group. The fact that this variable has a positive and significant effect only in 1997 can be attributed to either or both of the following considerations: (1) in this crisis year consumption-smoothing farm households would be especially likely to take advantage of the on-farm labor supply of members in this age group, and/or (2) because this was a good weather year, there would be more need for their labor than in the other survey years.

However, the results indicate that inter-household differences in farm income are determined to a larger extent by differences in land and agricultural assets than by differences in demographic characteristics. Of the land characteristics, the quantity of land (LANDSIZE) has a positive and significant influence in 1997, perhaps because of the adequacy of rainfall and other conditions for that year. The value of owned agricultural assets, a proxy for capital as well as embodied technology, has a positive and significant effect in both 1995 and 1997 but not in 2001. By contrast, the proportion of land in cooperatives has a positive impact only in 2001. These differences between the earlier years and 2001 are no doubt attributable to the important reform of cooperatives that took place after 1997 and which may have relieved households of the need to make use of as much of their own equipment. 
Table A2

Determinants of agricultural (or farm) income

\begin{tabular}{|c|c|c|c|}
\hline & 1995 & 1997 & 2001 \\
\hline Constant & $\begin{array}{l}5.8926 * * * \\
(1.2518)\end{array}$ & $\begin{array}{l}10.0863 \text { *** } \\
(1.7341)\end{array}$ & $\begin{array}{l}1.2069 \\
(1.5555)\end{array}$ \\
\hline AGE & $\begin{array}{l}0.0668 \\
(0.0533)\end{array}$ & $\begin{array}{l}0.0053 \\
(0.0779)\end{array}$ & $\begin{array}{l}0.0225 \\
(0.0647)\end{array}$ \\
\hline $\mathrm{AGE}^{2}$ & $\begin{array}{c}-0.0008 \\
(0.0006)\end{array}$ & $\begin{array}{c}-0.0046 \\
(0.0009)\end{array}$ & $\begin{array}{c}-0.0003 \\
(0.0007)\end{array}$ \\
\hline FEMALEH & $\begin{array}{l}0.0930 \\
(0.1878)\end{array}$ & $\begin{array}{c}-0.1423 \\
(0.2734)\end{array}$ & $\begin{array}{c}-0.0864 \\
(0.2484)\end{array}$ \\
\hline SECONDARYH & $\begin{array}{l}0.2298 \\
(0.1693)\end{array}$ & $\begin{array}{r}-0.2578 \\
(0.2537\end{array}$ & $\begin{array}{l}0.2796 \\
(0.2272)\end{array}$ \\
\hline VOCATIONALH & $\begin{array}{l}-0.2104 \\
(0.1394) \\
\end{array}$ & $\begin{array}{r}-0.3799 * \\
(0.2036) \\
\end{array}$ & $\begin{array}{l}0.1849 \\
(0.1572)\end{array}$ \\
\hline TERTIARYH & $\begin{array}{l}-0.9843 * * * \\
(0.2339)\end{array}$ & $\begin{array}{c}-0.9188 * * \\
(0.3602)\end{array}$ & $\begin{array}{l}0.0401 \\
(0.3368)\end{array}$ \\
\hline HHAGE0T6 & $\begin{array}{c}-0.0157 \\
(0.2436)\end{array}$ & $\begin{array}{c}-0.3267 \\
(0.3903)\end{array}$ & $\begin{array}{c}-0.4481 \\
(0.3620)\end{array}$ \\
\hline HHAGE7T18 & $\begin{array}{l}0.1803 \\
(0.1228)\end{array}$ & $\begin{array}{l}0.4013 * * \\
(0.1823)\end{array}$ & $\begin{array}{l}0.1558 \\
(0.1580)\end{array}$ \\
\hline HHAGEGT60 & $\begin{array}{l}0.0084 \\
(0.0937)\end{array}$ & $\begin{array}{l}0.1074 \\
(0.1530)\end{array}$ & $\begin{array}{c}-0.1812 \\
(0.1347)\end{array}$ \\
\hline HMARRIED & $\begin{array}{l}0.2774^{* *} \\
(0.1279)\end{array}$ & $\begin{array}{c}-0.0294 \\
(0.1868)\end{array}$ & $\begin{array}{l}0.0071 \\
(0.1526)\end{array}$ \\
\hline LANDSIZE & $\begin{array}{c}-0.0941 \\
(0.0766)\end{array}$ & $\begin{array}{l}0.0160 * * \\
(0.0080)\end{array}$ & $\begin{array}{l}0.2064 \\
(0.3293)\end{array}$ \\
\hline$\overline{P C O O P}$ & $\begin{array}{l}-0.2542 \\
(0.2259) \\
\end{array}$ & $\begin{array}{c}-0.1202 \\
(0.2405) \\
\end{array}$ & $\begin{array}{l}1.0743 * * * \\
(0.3493)\end{array}$ \\
\hline ORCHARD & $\begin{array}{l}-2.6811^{* * *} \\
(0.8444)\end{array}$ & $\begin{array}{c}-0.4105 \\
(0.9722)\end{array}$ & $\begin{array}{l}-0.7349 \\
(1.8418)\end{array}$ \\
\hline PASTURE & $\begin{array}{l}0.9647 \\
(0.7145)\end{array}$ & $\begin{array}{l}1.7402 * \\
(0.9116)\end{array}$ & $\begin{array}{l}0.7381 \\
(1.0546) \\
\end{array}$ \\
\hline RESTITUTED & $\begin{array}{l}0.1239 \\
(0.1412)\end{array}$ & $\begin{array}{l}0.2292 \\
(02038)\end{array}$ & $\begin{array}{l}0.2924 * \\
(0.1787)\end{array}$ \\
\hline AGASSETS & $\begin{array}{l}1.16 \mathrm{e}-06 * * \\
(5.17 \mathrm{e}-07)\end{array}$ & $\begin{array}{l}5.81 \mathrm{e}-08 * * \\
(2.31 \mathrm{e}-08)\end{array}$ & $\begin{array}{l}0.0001 \\
(0.0000)\end{array}$ \\
\hline Regions & Yes*** & Yes & Yes $* * *$ \\
\hline LANDSIZE $\times$ Regions & Yes*** & Yes*** & Yes*** \\
\hline ORCHARD $\times$ Regions & Yes & Yes & Yes \\
\hline PASTURE $\times$ Regions & Yes** & Yes & Yes \\
\hline $\begin{array}{l}\text { F-statistic } \\
(\text { Prob > F) }\end{array}$ & $\begin{array}{l}6.04 \\
(0.000)\end{array}$ & $\begin{array}{l}2.94 \\
(0.000)\end{array}$ & $\begin{array}{l}5.41 \\
(0.000)\end{array}$ \\
\hline Adjusted R-square & 0.2304 & 0.1662 & 0.2021 \\
\hline $\mathrm{N}$ obs & 558 & 538 & 532 \\
\hline
\end{tabular}

Notes: The figures within parentheses are robust standard errors. $* * *, * *$ and $*$ indicate significance at $1 \%, 5 \%$ and $10 \%$ levels, respectively. 